Hydrol. Earth Syst. Sci., 18, 1089-1103, 2014

www.hydrol-earth-syst-sci.net/18/1089/2014/

doi: 10.5194/hess-18-1089-2014

(C) Author(s) 2014. CC Attribution 3.0 License.

\title{
Identifying sources and controlling factors of arsenic release in saline groundwater aquifers
}

\author{
C.-W. Liu ${ }^{1}$, K.-L. Lu ${ }^{1}$, Y.-H. Kao ${ }^{1}$, C.-J. Wang ${ }^{1}$, S.-K. Maji ${ }^{1}$, and J.-F. Lee ${ }^{2}$ \\ ${ }^{1}$ Department of Bioenvironmental Systems Engineering, National Taiwan University, Taipei, Taiwan, 10617, ROC \\ ${ }^{2}$ National Synchrotron Radiation Research Center, Hsinchu, Taiwan, 300, ROC \\ Correspondence to: C.-W. Liu (cwliu@ntu.edu.tw)
}

Received: 21 July 2013 - Published in Hydrol. Earth Syst. Sci. Discuss.: 16 August 2013

Revised: - Accepted: 3 February 2014 - Published: 20 March 2014

\begin{abstract}
An integrated hydrogeochemical study was carried out to realize the occurrence of arsenic (As) in a saline aquifer. Saline groundwater was mostly concentrated in the uppermost aquifer, and non-saline water was in the lower aquifer in the study area. High As concentrations were found in both the uppermost and lower aquifers. No correlation among salinity, well depth and As concentration was observed. Various forms of $\mathrm{Fe}$ oxyhydroxides were identified in the magnetic fractions, which were concentrated by high gradient magnetic separation (HGMS) technique, revealing that the redox cycling of Fe occurred in the subsurface. High levels of $\mathrm{Fe}, \mathrm{HCO}_{3}^{-}$, DOC and $\mathrm{NH}_{4}^{+}$concentrations accompanying alkaline $\mathrm{pH}$ in the As-rich groundwater were consistent with the mechanism triggered by the microbially mediated reductive dissolution of $\mathrm{Fe}$ oxyhydroxides. A proposed threshold value of $50 \mu \mathrm{gL}^{-1}$ As concentration was used as an indicator for identification of active proceeding reductive dissolution of As-bearing Fe oxyhydroxides in the saline aquifer. Desorption behaviors of As were relevant to its valence in the sediments and the co-existence of anions. Experimental and numerical results showed that additions of $\mathrm{Cl}^{-}$ and $\mathrm{SO}_{4}^{2-}$, which represent the main anions of saline water, had minor effect on leaching sedimentary As. Although bicarbonate addition resulted in less As desorption than that of phosphate on a molar basis, the contribution of bicarbonate to the total release of As was greater than phosphate due to the much higher concentration of bicarbonate in shallow groundwater and the associated microbial mediation. Collectively, the chemical effect of saline water on the As release to groundwater is mild in the coastal aquifer.
\end{abstract}

\section{Introduction}

Arsenic (As) in groundwater exerts a serious environmental issue, notably in South Asia where local residents rely heavily on groundwater for drinking and agricultural purposes (Mandal et al., 1996; Smedley and Kinniburgh, 2002; Rodriguez-Lado et al., 2008; Shamsudduha et al., 2009). Utilization of this water leads to a variety of chronic illnesses, including skin lesions and cancers, both externally and internally (Mandal et al., 1996). In Taiwan, blackfoot disease (BFD), an As-related disease, was first reported and regarded as an endemical disease in Chianan Plain due to intake of artesian As-containing groundwater (Tseng, 1977). For the Choushui River alluvial fan, a neighboring region of Chianan Plain, As-contaminated aquifers are also found and distributed in the coastal area, with around $70 \%$ of monitoring wells exceeding the drinking water quality standard in Taiwan $\left(0.01 \mathrm{mg} \mathrm{L}^{-1}\right)$ (Liu et al., 2006; Taiwan Sugar Company, 2006). For these two catchments, although high As concentrations were observed at different depths, major characteristics of groundwater as well as the dominant release mechanism of As were similar, particularly at the BFD-endemic area (Wang et al., 2007; Lu et al., 2011).

In general, geogenic minerals such as Fe/Mn oxyhydroxides and As-bearing pyrite are the substantial compounds affecting the quantity of solid As in the subsurface (Smedley and Kinniburgh, 2002; Swartz et al., 2004; Drahota et al., 2009). Under either oxidizing or reducing conditions, subsequent transformation of these minerals accompanying the congruent release of As into groundwater have been proposed and well documented (Nickson et al., 2000; Harvey et al., 2002; Swartz et al., 2004; Hasan et al., 2009; Nath et al., 2009). Ionic competition as well as the change of $\mathrm{pH}$ and 
$E_{\mathrm{H}}$ also influences the mobility of As (Kim et al., 2000; $\mathrm{Su}$ and Pulse, 2001; Appelo et al., 2002; Harvey et al., 2002). The reductive dissolution of $\mathrm{Fe}$ oxyhydroxides mediated by microorganisms is a plausible process responsible for the enrichment of As in reducing groundwater systems (Ravencroft et al., 2009).

Regional surveys concerned with the partitioning of As within the subsurface in the Choushui River alluvial fan have been conducted by many researchers (Liu et al., 2003a, 2006; Wang et al., 2007, 2011; Lu et al., 2010, 2011). Sedimentary As contents increase significantly with the decrease of particle sizes. The predominant As-hosting minerals are iron oxyhydroxides and As-bearing sulfides. Regarding the aqueous phase, the enrichment of As in groundwater, mainly as As(III), is intimately involved with the redox processes. Initially, over-pumping results in the intrusion of air, causing the oxidation to immobilize minerals such as As-bearing pyrite, followed by the accumulation of $\mathrm{Fe}$ oxyhydroxides. Along with the gradual formation of reducing environment in the subsurface, the successive reductive dissolution of Fe oxyhydroxides is concurrent with the release of As into groundwater.

Saline water has high ionic concentrations, such as $\mathrm{Na}^{+}$, $\mathrm{K}^{+}, \mathrm{Mg}^{2+}, \mathrm{HCO}_{3}^{-}, \mathrm{Cl}^{-}$, and $\mathrm{SO}_{4}^{2-}$. The effect of ionic competition against the adsorption site of As onto the iron oxyhydroxides, and the microbial interaction that may enhance the arsenic dissolved in the saline aquifer, deserve further investigation.

Although several studies have been undertaken to investigate the distribution and occurrence of As in this area, the solid-phase influences on solution-phase arsenic concentrations, as well as the effect derived from saline water, remain unclear. Hence, the main purpose of this study is to comprehend the partition process of As in the saline sedimentary aquifer with respect to lithology, mineralogy, geochemistry and hydrochemistry. The association between Fe minerals and solid As is conducted and fractionated by a high gradient magnetic separation (HGMS) technique. Leaching behaviors of As are performed by batch experiments and modeled by the geochemical code (PHREEQC) (Parkurst and Appelo, 1999) with variation of major anions in saline groundwater. The results of the study are valuable to realize the chemical effect of saline water on the As release to groundwater in the coastal aquifer.

\section{Materials and methods}

\subsection{Site description and sampling}

The study area is located in the coastal area of the southern Choushui River alluvial fan, a major As-contaminated region in southwestern Taiwan (Fig. 1). The area is approximately $24 \mathrm{~km}^{2}$ with $24 \mathrm{~km}$ from north to south and $1 \mathrm{~km}$ from east to west. The average annual precipitation is $1417 \mathrm{~mm}$, most of which occurs over a 5-month period from June to Octo- ber. The subtropical climate is hot and humid, and typhoons often sweep across the island, bringing considerable precipitation in the summer. Due to demand and limited supply, groundwater is a vital water resource in this area. Substantial amounts of groundwater have been continuously extracted to meet aquacultural and agricultural needs. The coastal land is below sea level (Water Resources Agency, 2010). When a typhoon sweeps through western Taiwan, seawater breaks through the embankment and flows inland. In typhoon situations, the flooded coastal area requires more than 3 days to drain (Water Resources Agency, 2010).

The array of monitoring wells comprised 21 shallow and 7 deep wells, with depth ranging from 7 to $24 \mathrm{~m}$ and from 38 to $110 \mathrm{~m}$, respectively (Liu et al., 2003a). In this area, seasonal surveys of groundwater quality were undertaken by Tainan Hydraulics Laboratory from 1992 to 2004, and this study adopted the monitoring data for analyses (Tainan Hydraulic Laboratory, 1992-2004). To eliminate the fluctuations of seasonally measured groundwater quality, the timeaveraged values of aqueous parameters were used to represent the hydrochemistry of local groundwater.

In addition, two boreholes, (YL6-1 and YL7-1) which were located in around $10 \mathrm{~m}$ away from YL6 and YL7, respectively, contained higher As concentrations than other monitoring wells. These two wells, located in the uppermost aquitard, were purposefully drilled for the investigation of lithological, mineralogical and geochemical characteristics of As-rich saline aquifers from the surface to a depth of $25 \mathrm{~m}$ (Fig. 1). A drill rig and a split-tube sampler with $50 \mathrm{~mm}$ O.D. PVC liner were used to collect sediment cores in $100 \mathrm{~cm} \mathrm{seg-}$ ment. The core-ends were sealed in the field with paraffin wax to minimize the exposure to the atmosphere. Furthermore, core samples were stored at $4^{\circ}$ in polyethylene bags to reduce microbial activities before use.

\subsection{Analytical methods}

\subsubsection{Aqueous phase}

The field sampling methods used the NIEA code W103.50B, set by the Taiwan Environment Protection Administration. At least 3 wellbore volumes of groundwater were purged before sampling. Dissolved oxygen (DO), temperature ( $T$ ), $\mathrm{pH}$ and electrical conductivity (EC) were measured in a flow-through cell every 5 min during well purging. Cell sensors were calibrated with standard buffer solutions (all from Merck Co.), which have $\mathrm{pH}=4.0,7.0$, and $10.0 ; \mathrm{EC}=1410 \mu \mathrm{Scm}^{-1}$, in the field before measuring these parameters (APHA, 1998). Water samples were collected only after $\mathrm{pH}$ and EC stabilized, and the fluctuations of $\mathrm{pH}$ and relative EC were less than 0.1 and $5 \%$, respectively. After purging, a probe (MiniSonde, manufactured by HydroLab, USA), which is $5 \mathrm{~cm}$ in diameter and $70 \mathrm{~cm}$ in length (including a data logger, a circulator and 3 sensors for DO, $T$, EC, and $\mathrm{pH}$ measurements) was lowered down to the screen position of the well casing 


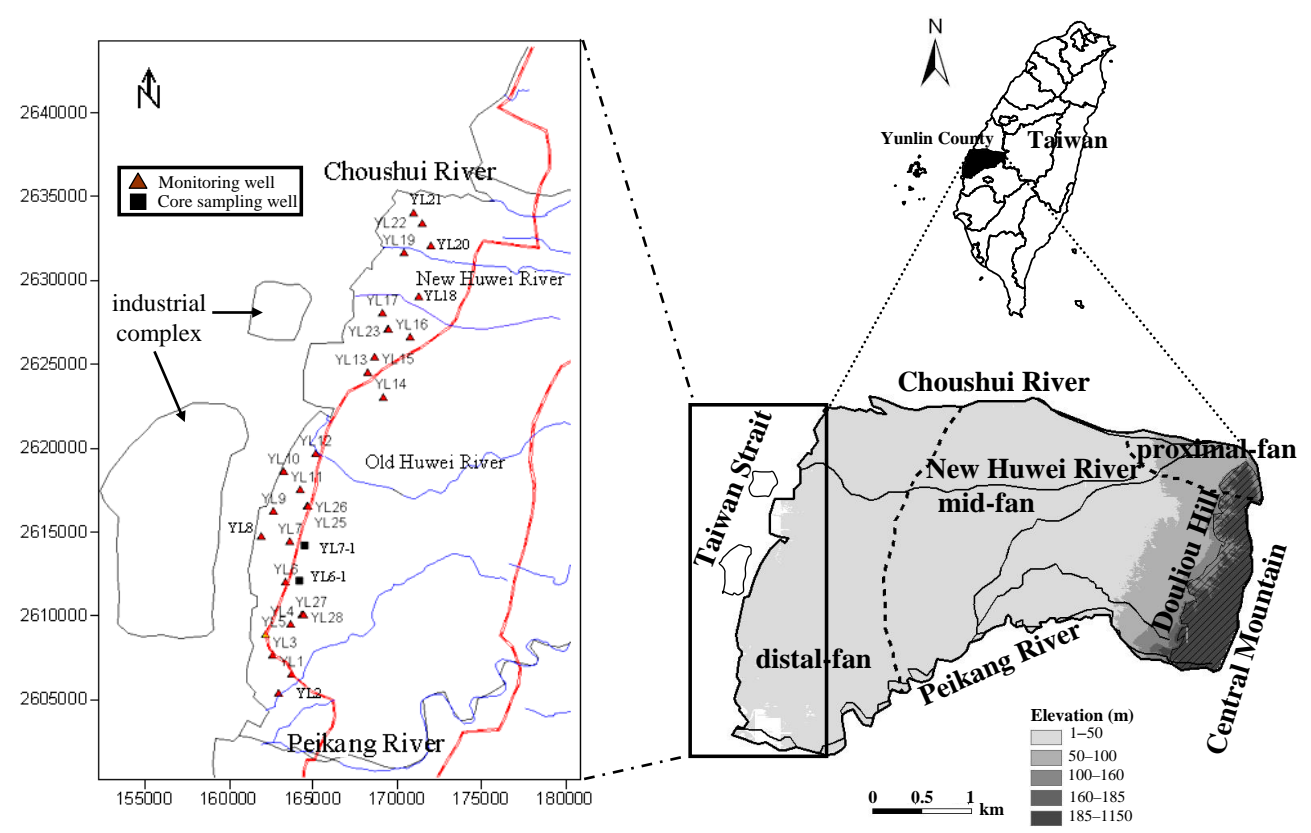

Fig. 1. Location of study area in the coastal area of the Choushui River alluvial fan, Taiwan. Triangle and square symbols represented groundwater and core sampling wells, respectively. Offshore industrial complexes are man-made islands for oil refinery plants.

and remained there for at least $10 \mathrm{~min}$ before water quality parameters were recorded (Chen and Liu, 2003).

Water samples for metal and other cations' measurements were filtered by $0.45 \mu \mathrm{m}$ glass fiber papers and acidified with $\mathrm{HNO}_{3}$ (Merck ultrapure grade) to $\mathrm{pH}$. Samples were then kept in ice boxes and delivered to the laboratory within $24 \mathrm{~h}$. Dissolved ion concentrations were determined by conventional methods (APHA, 1998). The concentrations of major anions $\left(\mathrm{Cl}^{-}, \mathrm{BNO}_{3}^{-}\right.$, and $\left.\mathrm{SO}_{4}^{2-}\right)$ and cations $\left(\mathrm{Na}^{+}, \mathrm{BK}^{+}\right.$, $\mathrm{BCa}^{2+}, \mathrm{BMg}^{2+}$, and $\mathrm{NH}_{4}^{+}$) in groundwater samples were analyzed by Dionex DX-120 ion chromatography. Iron concentration was measured with inductively coupled plasma and atomic emission spectrometry (ICP-AES) (Varian, VISTAMPX). Arsenic concentration was analyzed using an electrothermal atomic absorption spectrometer (AAS, Perkin-Elmer AA100) and a hydride generation (HG) system (PerkinElmer FIAS100); $0.5 \% \mathrm{NaBH}_{4}$ in $0.25 \% \mathrm{NaOH}$ and $1 \mathrm{M}$ $\mathrm{HCl}$ were added to reduce arsenic to arsine. Four major As species, As(III), As(V), methylarsonic acid (MMA) and dimethylarsinic acid (DMA), were separated using an anion column (Phenomenex, Macherey-Nagel, Germany; Nucleosil, $10 \mu \mathrm{m}, 250 \mathrm{~mm} \times 4.6 \mathrm{~mm}$ ), connected with an highperformance liquid chromatograph (HPLC) (Perkin Elmer, Series 200), which was interfaced to an electro-thermal atomic absorption spectrometer (AAS) (Perkin-Elmer, AA 200) and a hydride generation (HG) system (Perkin-Elmer, FIAS 100) (Huang et al., 2003). The recovery rate of As(III) and $\mathrm{As}(\mathrm{V})$ yielded $100.7 \pm 3.8 \%$ and $97.2 \pm 4.0 \%$, respectively. Dissolved organic carbon (DOC) was measured using the high temperature combustion method (APHA, 1998).

\subsubsection{Solid phase}

Sediment samples were freeze-dried, ground and sieved to ensure representative sampling. The contents of $\mathrm{As}$ and $\mathrm{Fe}$ in the cores were determined following EPA 3050B. Main compositions in the core samples were determined by X-ray fluorescence (XRF) (Spectro, XEPOS). Percent abundance of total carbon was determined with a model $2400 \mathrm{CHN}$ analyzer (VarioEL-III, Heraeus, Germany). Total organic carbon (OC) was then determined by subtracting the amount of carbon present as carbonate from the total amounts of carbon.

Different particle size fractions of freeze-dried samples were performed by dry-sieving for mineralogical analysis. Density separation was conducted on freeze-dried samples for each of six depths $(8,10,13,15,17$, and $21 \mathrm{~m}$ for YL61 and $8,10,14,17,21$, and $24 \mathrm{~m}$ for YL7-1) of two boreholes to quantify As associations as a function of Fe contents. The clay samples were dispersed in $\mathrm{H}_{2} \mathrm{O}$, and fine $(<1 \mu \mathrm{m})$ and coarse clay $(1-2 \mu \mathrm{m})$ fractions were separated by centrifugation (Jackson, 1979). The silt was segregated from the sand by wet-sieving ( $53 \mu \mathrm{m}$ sieve). The clay fractions were dialyzed against double distilled water (DDW) and then freeze-dried. Clays were separated into magnetic and nonmagnetic fractions using a high-gradient magnetic separation (HGMS) technique (Schulze and Dixon, 1979). Total As and $\mathrm{Fe}$ contents in these fractions were also determined. Mineralogy of iron was determined using a high-resolution X-ray photoelectron spectrometer (HR-XPS) (PHI Quantera $\mathrm{SXM}$ ), which was equipped with a $\mathrm{K} \alpha \mathrm{X}$-ray beam at $3.8 \mathrm{~kW}$ generated from an $\mathrm{Al}$ rotating anode. Each spectrum was 
obtained by plotting the measured photoelectron intensity as a function of the binding energy (BE). Binding energies of photoelectrons were calibrated by the aliphatic adventitious hydrocarbon $\mathrm{C}(1 \mathrm{~s})$ peak at $284.6 \mathrm{eV}$.

Arsenic in the sediments used in leaching experiments was analyzed with X-ray absorption, near-edge structure (XANES) spectra to determine arsenic speciation. X-ray absorption spectra (XAS) at the As K-edge $(11867 \mathrm{eV})$ were collected at the Wiggler 20 beamline BL-17C at the National Synchrotron Radiation Research Center (NSRRC), Hsin-Chu, Taiwan. Beamline Wiggler 20 (17C), with energy ranging from 4 to $15 \mathrm{keV}$, employs a $\mathrm{Si}(111)$ double-crystal monochromator for energy scanning with a resolving power $(E / \Delta E)$ of 7000 and beam intensity of around $10^{9} \sim 10^{10}$ photons per s. All samples were fixed onto an aluminum holder, sealed with Kapton tape and placed at $45^{\circ}$ to the $\mathrm{X}$-ray beam. Sample spectra were collected from -50 to + $100 \mathrm{eV}$ around the $\mathrm{As} \mathrm{K}_{\alpha}$ edge of $11867 \mathrm{eV}$ and compared to XANES spectra of selected reference standards, including arsenate $\left(\mathrm{Na}_{2} \mathrm{HAsO}_{4} \cdot 7 \mathrm{H}_{2} \mathrm{O}\right)$ and arsenite $\left(\mathrm{NaAsO}_{2}\right)$. In addition, the $\mathrm{Au} L_{3}$-edge spectrum was monitored by the $I_{\mathrm{r}}$ chamber simultaneously with $I_{\mathrm{t}}$ and $I_{\mathrm{f}}$ chambers, serving as the reference to calibrate energy shift due to monochromator drifts. Several scans were processed and averaged on each sample to improve the data quality of XAS spectra. The Athena program was used for standard background subtraction and edge-height normalization using the AUTOBK algorithm (Ravel and Newville, 2005).

\subsection{Batch desorption experiments}

Batch experiments were performed to investigate the effect of major saline anions and phosphate ions on arsenic desorption from the sediment samples under atmospheric condition. In reference to local saline groundwater composition as well as those used in the literature, four kinds of anions in the local saline groundwater, including $\mathrm{Cl}^{-}, \mathrm{SO}_{4}^{2-}, \mathrm{HCO}_{3}^{-}$and $\mathrm{PO}_{4}^{3-}$, were selected to conduct leaching experiment to assess the competitive effects of various anions on As release. Except $\mathrm{PO}_{4}^{3-}$, four levels of concentrations $(0.001,0.01,0.1$, and $1 \mathrm{M}$ ) were used. These concentrations bracketed the highest and lowest concentrations of the respective anions expected to be found in the local area. Phosphate generally has low concentration in groundwater due to a strong bond of phosphate with clay minerals and metal hydroxides, particularly iron hydroxides, as well as its use in the biological cycle (Matthess, 1982). For phosphate, only three levels of concentrations $(0.001,0.01$, and $0.1 \mathrm{M})$ were designed. The supply of phosphorus concentration in the local groundwater of the study area was generally from the use of agrochemicals and household detergents.

The stock solutions of competitive anions were prepared in the laboratory by dissolving pre-weighted amounts of reagents of $\mathrm{NaCl}, \mathrm{Na}_{2} \mathrm{SO}_{4}, \mathrm{NaHCO}_{3}$, and $\mathrm{NaH}_{2} \mathrm{PO}_{4}$, into DDW. The $\mathrm{pH}$ of these solutions was adjusted to around
7. For each trial, $0.2 \mathrm{~g}$ of dried sediments, which were well within the screen range of YL6-1 (16 m) and YL7-1 (18 m), was mixed with $3 \mathrm{~mL}$ of solution in a $50 \mathrm{~mL}$ centrifuge tube. The reaction flask was shaken at approximately $150 \mathrm{rpm}$ by a reciprocal shaker, lasting at least 30 days. After a specific period of shaking, an aliquot of the leachate was filtrated with $0.22 \mu \mathrm{m}$ filter before analysis of the As concentration.

\subsection{Numerical simulation}

The numerical program, PHREEQC (Parkurst and Appelo, 1999) was adopted to model the batch experiments of desorption processes of arsenic from the YL6-1 and YL7-1 core samples under various anionic concentrations. PHREEQC is based on the equilibrium chemistry of aqueous solutions interacting with minerals, gases, solid solutions, exchangers and sorption surfaces. These processes can be combined with equilibrium and/or chemical kinetic reactions. Several processes have been accounted for in the basic calculation in the study, including equilibrated speciation, equilibrium phases, surface sorption and kinetic desorption that mimic the batch experimental conditions.

\section{Results}

\subsection{Description of groundwater quality}

Table 1 lists the physicochemical data of groundwater samples. The pH of sampled wells was mostly above 7 and characterized as mild alkaline with the highest $\mathrm{pH}$ of 8.6 in YL14. Temperatures of all samples were uniform with an average of $26.0^{\circ}$. To classify the major ions for groundwater and summarize the main distinctions in hydrogeochemical composition between different water sources, a Piper diagram was used. Plots of major ions on the Piper diagram showed that most samples, 12 out of 28 wells, were categorized into Group 4 of saline type, and 5, 7 and 4 samples were in Groups 1 (temporary hardness), 2 (alkali carbonate), and 3 (permanent hardness), respectively (Fig. 2). Local groundwaters were characterized as $\mathrm{NaCl}$ or $\mathrm{Na}-\mathrm{Mg}-\mathrm{HCO}_{3}$ type. Notably, the NaCl-type samples were concentrated in the southern part of the aquifer in contrast to the $\mathrm{Na}-\mathrm{Mg}-\mathrm{HCO}_{3}$ type in the northern part. High EC values correlating well with $\mathrm{Na}$ and $\mathrm{Cl}\left(r^{2}=0.99, p<0.01\right)$ revealed the severe salination in groundwater (Liu et al., 2003a). The major causes of shallow groundwater salinization were the vertical infiltration of salt water from fish pond farming and the seawater flooding in the subsident coastal area. Seawater intrusion plays a minor role on the local groundwater salinization, due to aquifers that are enclosed by the aquitard, and does not directly contact the seawater (Liu et al., 2003b)

Referring to $N$ species, $\mathrm{NH}_{4}^{+}$was the dominant species $\left(0.2-20.3 \mathrm{mg} \mathrm{L}^{-1}\right)$, indicating the presence of reducing conditions in this region ( $\mathrm{Lu}$ et al., 2011). Alkalinization of 
Table 1. Mean values of hydrogeochemical compositions of groundwater among monitoring wells in the coastal area of the Choushui River alluvial fan from 1992 to 2004.

\begin{tabular}{|c|c|c|c|c|c|c|c|c|c|c|c|c|c|c|c|c|}
\hline \multirow[t]{2}{*}{ No. } & \multirow[t]{2}{*}{$\mathrm{pH}$} & \multirow{2}{*}{$\begin{array}{l}T \\
\left({ }^{\circ}\right)\end{array}$} & \multirow{2}{*}{$\begin{array}{r}\text { EC } \\
\left(\mu \mathrm{Scm}^{-1}\right)\end{array}$} & TDS & $\mathrm{Ca}^{2+}$ & $\mathrm{Mg}^{2+}$ & $\mathrm{Na}^{+}$ & $\mathrm{K}^{+}$ & $\mathrm{SO}_{4}^{2-}$ & $\mathrm{Cl}^{-}$ & $\mathrm{NO}_{3}^{-}$ & $\mathrm{NH}_{4}^{+}$ & $\mathrm{HCO}_{3}^{-}$ & DOC & As & $\mathrm{Fe}$ \\
\hline & & & & \multicolumn{11}{|c|}{$\left(\mathrm{mgL}^{-1}\right)$} & \multicolumn{2}{|c|}{$\left(\mu \mathrm{gL}^{-1}\right)$} \\
\hline YL 1 & 7.8 & 25.9 & 2410.8 & 1673.7 & 120.0 & 95.4 & 303.7 & 44.6 & 278.6 & 397.2 & 1.0 & 1.2 & 691.9 & 2.2 & 28.3 & 410 \\
\hline YL 2 & 7.6 & 25.4 & 34987.9 & 26427.1 & 230.4 & 625.5 & 5959.9 & 304.0 & 1090.8 & 10526.5 & 2.8 & 20.3 & 3151.3 & 2.7 & 21.5 & 730 \\
\hline YL 3 & 7.9 & 26.2 & 13127.0 & 10273.0 & 169.2 & 536.4 & 2165.0 & 142.8 & 153.8 & 3994.7 & 1.3 & 18.1 & 1726.8 & 2.2 & 103.1 & 440 \\
\hline YL 4 & 7.9 & 26.3 & 5797.4 & 4143.2 & 118.4 & 150.5 & 795.7 & 85.1 & 163.1 & 1541.6 & 0.5 & 11.8 & 914.3 & 1.8 & 77.6 & 450 \\
\hline YL 5 & 7.8 & 26.1 & 18236.5 & 14080.5 & 164.2 & 314.3 & 2781.2 & 198.1 & 431.2 & 5558.5 & 2.6 & 15.9 & 1703.6 & 2.6 & 9.5 & 610 \\
\hline YL 6 & 8.1 & 25.6 & 12194.5 & 9216.5 & 46.3 & 164.2 & 2351.4 & 126.8 & 370.6 & 3610.1 & 2.0 & 14.0 & 630.9 & 5.2 & 175.4 & 330 \\
\hline YL 7 & 8.0 & 25.7 & 2038.9 & 1409.5 & 50.0 & 68.7 & 283.7 & 37.4 & 57.9 & 360.1 & 0.3 & 7.4 & 678.7 & 3.6 & 533.1 & 590 \\
\hline YL 8 & 7.7 & 26.7 & 24176.9 & 19722.5 & 254.2 & 518.0 & 4409.2 & 171.7 & 1052.5 & 7594.3 & 0.7 & 2.2 & 2393.7 & 1.3 & 11.1 & 370 \\
\hline YL 9 & 8.3 & 26.4 & 3752.2 & 2803.1 & 14.0 & 22.7 & 810.9 & 51.8 & 188.2 & 820.4 & 2.0 & 8.7 & 623.4 & 17.4 & 477.5 & 930 \\
\hline YL 10 & 7.9 & 26.5 & 25730.7 & 20420.2 & 198.6 & 431.4 & 4412.8 & 185.6 & 1131.5 & 7407.6 & 1.5 & 2.0 & 1760.7 & 1.6 & 93.0 & 370 \\
\hline YL 11 & 8.2 & 25.3 & 1173.2 & 797.1 & 26.2 & 27.4 & 213.6 & 47.1 & 29.1 & 125.2 & 0.7 & 3.1 & 178.1 & 2.4 & 83.3 & 420 \\
\hline YL 12 & 7.9 & 26.0 & 13236.1 & 10053.9 & 201.4 & 276.3 & 2181.3 & 109.5 & 651.3 & 3894.9 & 1.5 & 4.1 & 1640.2 & 1.5 & 47.3 & 240 \\
\hline YL 13 & 7.6 & 26.4 & 17121.9 & 13099.2 & 250.3 & 243.3 & 2758.0 & 118.6 & 813.1 & 4862.2 & 0.7 & 3.4 & 1581.1 & 1.1 & 42.8 & 630 \\
\hline YL 14 & 8.6 & 26.3 & 1355.2 & 916.0 & 11.2 & 12.82 & 309.8 & 15.8 & 126.2 & 93.4 & 0.6 & 0.6 & 80.6 & 2.7 & 31.4 & 1180 \\
\hline YL 15 & 7.8 & 25.7 & 6483.2 & 5122.0 & 196.6 & 155.0 & 1052.6 & 41.1 & 355.0 & 1759.1 & 1.5 & 2.6 & 1216.4 & 2.3 & 111.2 & 290 \\
\hline YL 16 & 7.5 & 25.6 & 1280.8 & 859.1 & 169.8 & 48.8 & 73.2 & 5.9 & 300.6 & 45.5 & 5.6 & 0.2 & 624.6 & 1.2 & 6.7 & 340 \\
\hline YL 17 & 7.8 & 26.2 & 1118.7 & 740.1 & 71.9 & 24.9 & 158.9 & 12.7 & 48.2 & 151.8 & 2.9 & 3.7 & 281.9 & 2.1 & 60.1 & 560 \\
\hline YL 18 & 7.6 & 26.6 & 1759.7 & 1207.0 & 171.6 & 84.9 & 121.3 & 20.3 & 449.4 & 157.5 & 0.9 & 0.4 & 777.4 & 1.2 & 19.5 & 410 \\
\hline YL 19 & 7.7 & 26.1 & 17370.3 & 12509.5 & 150.8 & 327.6 & 2904.5 & 144.8 & 507.8 & 5168.0 & 0.4 & 12.5 & 1724.8 & 2.1 & 36.9 & 1010 \\
\hline YL 20 & 7.7 & 25.9 & 1129.8 & 779.8 & 107.5 & 25.5 & 139.3 & 4.8 & 126.3 & 129.4 & 0.2 & 1.1 & 373.3 & 1.3 & 20.0 & 280 \\
\hline YL 21 & 7.8 & 26.5 & 1110.9 & 743.6 & 71.0 & 45.7 & 143.3 & 18.9 & 152.7 & 107.3 & 0.5 & 0.6 & 365.5 & 2.7 & 7.5 & 270 \\
\hline YL 22 & 8.0 & 25.7 & 554.9 & 350.0 & 42.7 & 22.1 & 49.3 & 4.9 & 46.3 & 6.4 & 0.3 & 2.2 & 197.9 & 1.8 & 226.1 & 370 \\
\hline YL 23 & 8.2 & 25.5 & 579.3 & 367.7 & 23.8 & 38.1 & 44.1 & 21.2 & 38.7 & 8.5 & 0.7 & 0.7 & 216.3 & 1.2 & 10.4 & 520 \\
\hline YL 24 & 8.0 & 25.5 & 546.5 & 358.2 & 49.6 & 15.1 & 54.2 & 2.4 & 16.3 & 27.9 & 0.5 & 0.6 & 186.2 & 1.7 & 18.8 & 290 \\
\hline YL 25 & 8.3 & 26.8 & 831.4 & 527.0 & 12.5 & 29.9 & 147.4 & 34.2 & 7.7 & 11.0 & 0.9 & 4.8 & 123.5 & 3.2 & 120.7 & 190 \\
\hline YL 26 & 8.1 & 26.6 & 434.8 & 277.2 & 31.8 & 7.6 & 63.5 & 3.2 & 3.9 & 6.6 & 0.4 & 0.8 & 111.1 & 1.6 & 36.5 & 380 \\
\hline YL 27 & 8.0 & 26.3 & 690.4 & 450.3 & 45.5 & 22.6 & 72.0 & 18.0 & 37.1 & 33.3 & 5.8 & 0.2 & 207.6 & 2.9 & 21.9 & 130 \\
\hline YL 28 & 7.7 & 25.9 & 753.0 & 488.2 & 44.6 & 19.0 & 90.2 & 14.8 & 16.1 & 48.0 & 6.0 & 0.5 & 189.4 & 3.1 & 66.3 & 260 \\
\hline
\end{tabular}

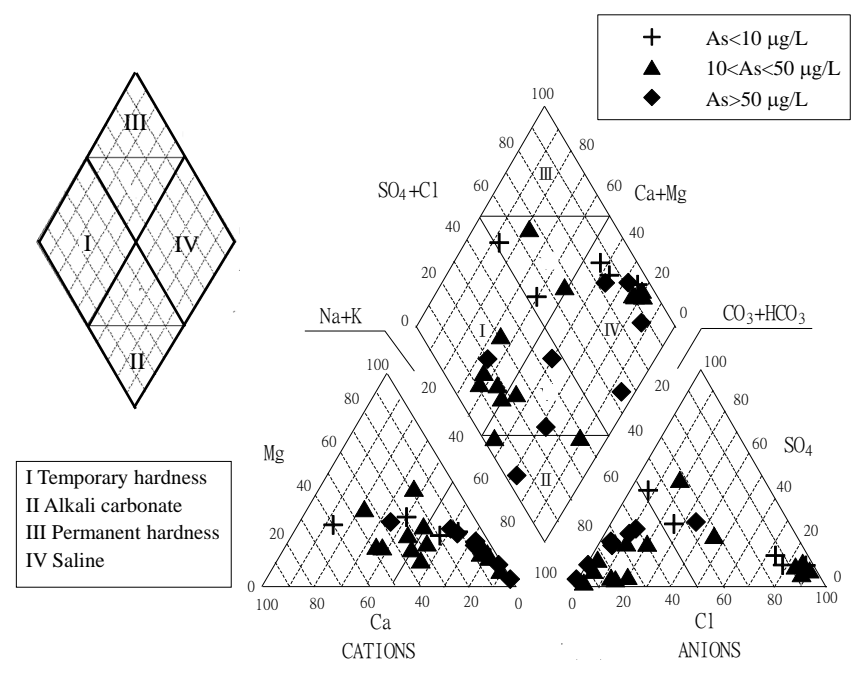

Fig. 2. Piper plot of sampled groundwaters in the littoral area of the Choushui River alluvial fan.

groundwater was evidenced by high levels of $\mathrm{pH}$ and $\mathrm{HCO}_{3}^{-}$ concentrations (Stumm and Sulzberger, 1992). High $\mathrm{HCO}_{3}^{-}$ concentration may originate from silicate weathering, oxidation of organic carbon and carbonate dissolution (Mukherjee and Fryar, 2008). The Na-normalized $\mathrm{Ca}$ versus $\mathrm{HCO}_{3}^{-}$ and $\mathrm{Mg}$ plots (Wang et al., 2012) suggest that the silicate weathering may be the main process that occurred during the Holocene transgression. The weathering processes facilitated the formation of secondary clay minerals and $\mathrm{Fe}$ oxides, which provided sufficient sorption sites for the As enrichment of solids (Berg et al., 2008). Moreover, dissolved organic matter can be another active source for $\mathrm{HCO}_{3}^{-}$ in groundwater under reducing conditions. Arsenic concentrations also showed a heterogeneous distribution over the whole study area, spreading from 6.7 to $533.1 \mu \mathrm{gL}^{-1}$, with a mean value of $89.2 \mu \mathrm{gL}^{-1}$. According to the data, 25 out of 28 wells exceed the Taiwanese limitation of As concentration for drinking water $\left(10 \mu \mathrm{L} \mathrm{L}^{-1}\right)$ and 12 out of 28 wells were above the concentration of $50.0 \mu \mathrm{gL}^{-1}$. Notably, electrical conductivity (EC) values varied heterogeneously but were higher in the shallow wells (YL1-YL21), spanning more than one order of magnitude among wells (Fig. 3a). The EC values of deep wells (YL22-YL28) were all less than $900 \mu \mathrm{sm}^{-1}$, suggesting that the lower aquifer was not affected by saline water intrusion. However, groundwater at shallow salinized water wells, e.g., YL5 and YL16, did not necessarily contain higher As concentrations than those in the deeper water wells, e.g., YL22 and YL25. No correlations were found among EC, depth and As concentration (Fig. 3b). Iron concentrations were moderate, reaching up to $1140 \mu \mathrm{gL}^{-1}$. Of all the sampled waters, $73 \%$ exceed the WHO guideline value of $300 \mu \mathrm{gL}^{-1}$ for $\mathrm{Fe}$ (WHO, 2002). 
(a)

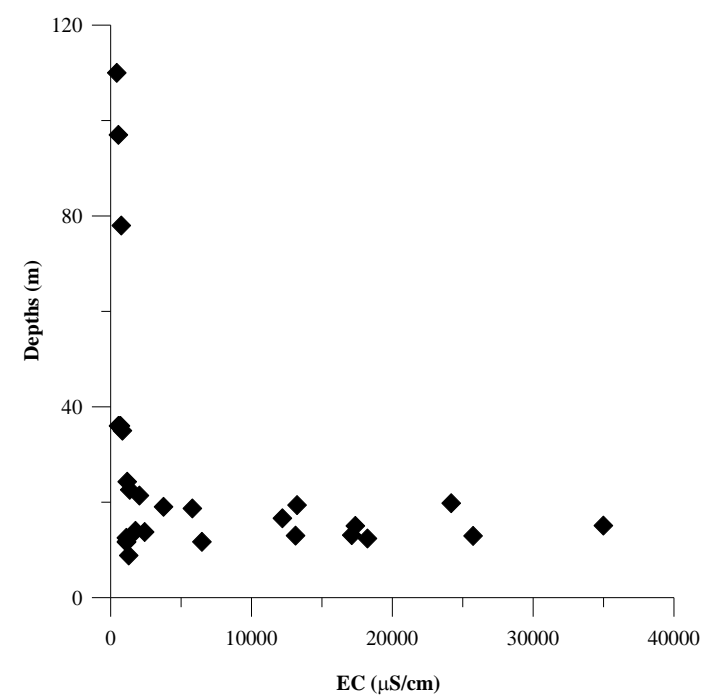

(b)

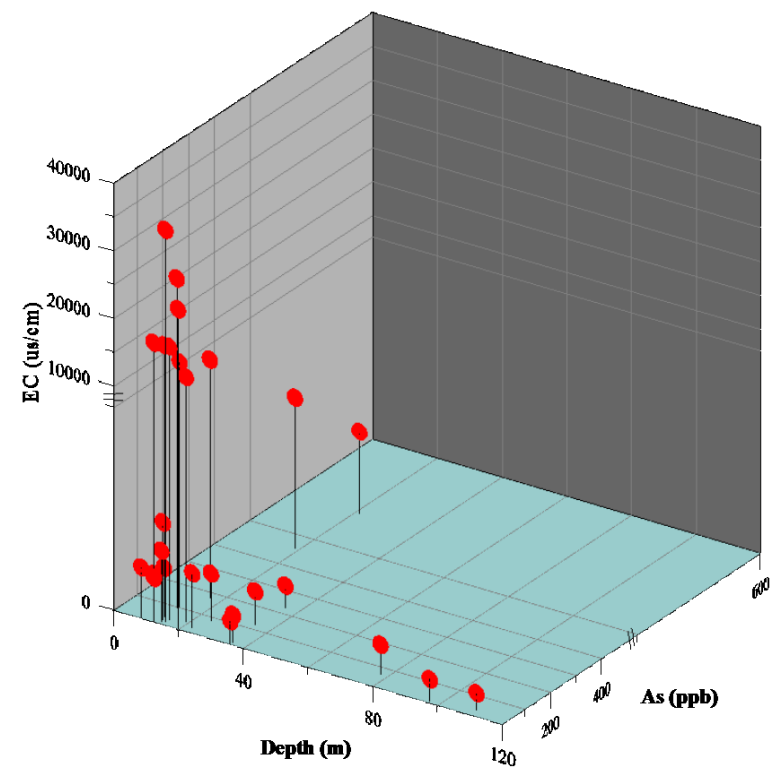

Fig. 3. (a) Scatter plot of EC and well depth of YL1-YL28. (b) Three dimensional plot of EC, As concentration and well depth of YL1-YL28.

\subsection{Mineralogical and geochemical characterization of saline sedimentary aquifer}

The sedimentary sequence of alternating unconsolidated clays and sands from both boreholes exhibited dissimilar patterns, particularly at the top layer and screen range (Fig. 4). The sediments ranged in texture from gravel to clay and in color from grey to black. The top layer for both boreholes consisted of various capped soils (0-3 m). At greater depths, the remaining silty sand and following sand were grey to black in color. The gradual refining sequences of deposits
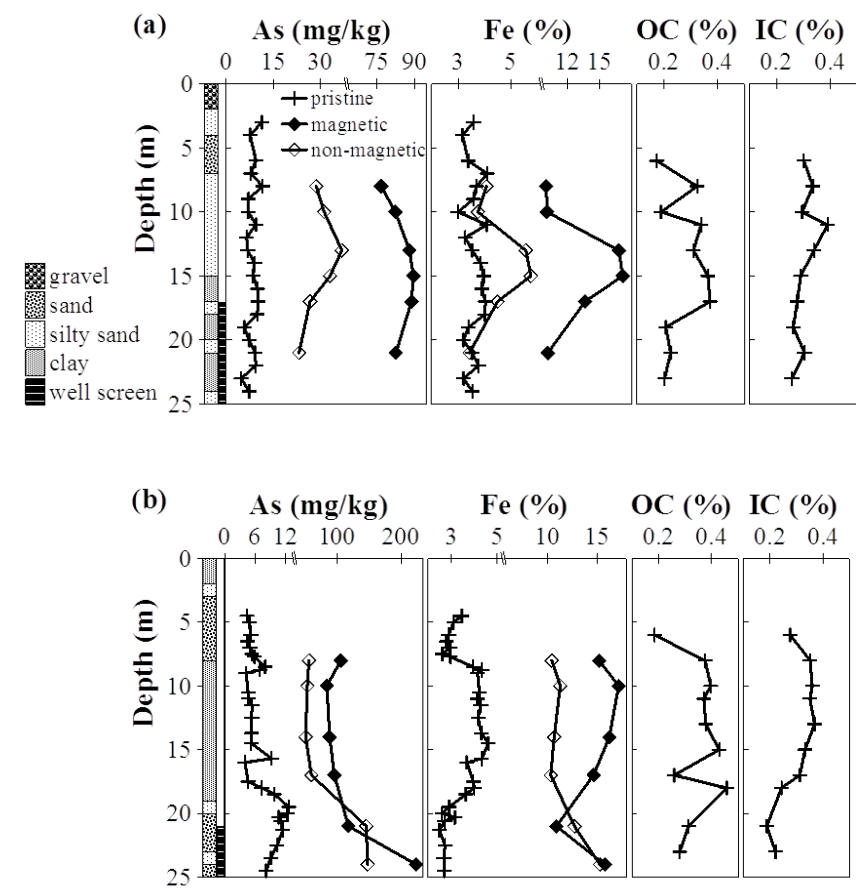

Fig. 4. Geochemistry distribution of As, Fe, and organic and inorganic carbon contents along the depth in (a) YL6-1 and (b) YL7-1. Solid crosses and diamonds represent untreated (pristine) samples and magnetic fractions, respectively. Hollow diamonds represent non-magnetic fractions. For magnetic and non-magnetic fractions, only As and Fe contents were measured.

of both boreholes were suggestive of deposition in a fluvial environment. The sediment is grey to dark in nature. The biostratigraphic analysis indicated that the formation age is Holocene (Huang, 1996). In contrast to silty sand interlayered with clay as the main composition of the screen range of YL6-1, the screen range of YL7-1 was mainly comprised of sand, revealing the heterogeneous depositing process, even within a distance of $2.5 \mathrm{~km}$. The observed fine-grained sediments in the upper layer (3-19 m) locally acted as aquitards, however, they vary significantly on a regional scale (Liu et al., 2003b).

Geochemical profiles of both YL6-1 and YL7-1 were depicted with respect to total As, Fe and organic/inorganic carbon (OC/IC) contents (Fig. 4). The solid As ranged from 4.69 to $11.53 \mathrm{mg} \mathrm{kg}^{-1}$ with a mean value of $8.30 \mathrm{mg} \mathrm{kg}^{-1}$ for YL6-1 and from 4.02 to $12.77 \mathrm{mg} \mathrm{kg}^{-1}$ with a mean value of $7.21 \mathrm{mg} \mathrm{kg}^{-1}$ for YL7-1. The Fe contents varied from 3.0 to $4.1 \%$ and from 2.5 to $4.6 \%$ with separate mean values of 3.6 and $3.5 \%$ for YL6-1 and YL7-1, respectively. There were no significant vertical variations of As and Fe contents observed in the core profile of YL6-1. However, contrary to the increasing trend of solid As within the screen range of YL7-1, the declining Fe amounts were measured. The As and $\mathrm{Fe}$ contents of these two cores were within the typical range of the sediments observed in other As-affected areas 
Table 2. Major elements (wt\%), arsenic and manganese $\left(\mathrm{mgkg}^{-1}\right)$ contents in core samples.

\begin{tabular}{|c|c|c|c|c|c|c|c|c|c|c|c|}
\hline \multirow[t]{2}{*}{ Bore no. } & \multirow{2}{*}{$\begin{array}{c}\text { Depth } \\
\text { (m) }\end{array}$} & \multirow[t]{2}{*}{ Lithology color/type } & $\mathrm{Si}$ & $\mathrm{Al}$ & $\mathrm{Fe}$ & $\mathrm{K}$ & $\mathrm{Ca}$ & $\mathrm{Mg}$ & $\mathrm{S}$ & As & $\mathrm{Mn}$ \\
\hline & & & \multicolumn{6}{|c|}{$\%$} & \multicolumn{3}{|c|}{$\mathrm{mg} \mathrm{kg}^{-1}$} \\
\hline \multirow[t]{10}{*}{ YL6-1 } & 6.5 & black/fine sand & 37.6 & 10.2 & 4.0 & 2.8 & 1.3 & 0.5 & 1241.0 & 9.4 & 132.6 \\
\hline & 8.5 & black/silty clay & 40.2 & 12.4 & 3.7 & 3.2 & 1.7 & 0.9 & 1245.0 & 11.5 & 203.7 \\
\hline & 10.5 & black/silty clay & 37.1 & 10.4 & 3.0 & 2.8 & 1.5 & 0.5 & 821.3 & 7.0 & 101.7 \\
\hline & 11.5 & black/silty clay & 40.7 & 13.9 & 4.1 & 3.5 & 1.7 & 1.1 & 988.4 & 9.4 & 225.9 \\
\hline & 13.5 & black/silty clay & 39.4 & 11.4 & 3.5 & 2.9 & 1.8 & 0.7 & 794.9 & 6.8 & 159.0 \\
\hline & 15.5 & black/clay & 39.5 & 12.7 & 4.0 & 3.3 & 1.6 & 0.9 & 887.7 & 8.5 & 208.0 \\
\hline & 17.5 & black/clay & 40.2 & 13.7 & 4.0 & 3.5 & 1.5 & 1.0 & 933.5 & 10.1 & 179.6 \\
\hline & 19.5 & black/clay & 35.6 & 11.3 & 3.4 & 3.0 & 1.2 & 0.6 & 475.0 & 5.7 & 99.3 \\
\hline & 21.5 & black/silty clay & 37.9 & 12.1 & 3.5 & 3.1 & 1.4 & 0.9 & 824.0 & 9.2 & 163.3 \\
\hline & 23.5 & black/clay & 37.7 & 10.5 & 3.2 & 2.9 & 1.3 & 0.6 & 513.1 & 4.7 & 94.7 \\
\hline \multirow[t]{9}{*}{ YL7-1 } & 6.5 & dark grey/fine sand & 38.1 & 10.3 & 2.8 & 2.7 & 1.7 & 0.5 & 433.2 & 4.6 & 127.9 \\
\hline & 8.5 & dark grey/fine sand & 40.6 & 12.4 & 4.0 & 3.1 & 2.2 & 0.9 & 1225.0 & 8.0 & 204.8 \\
\hline & 10.5 & dark grey/silty clay & 40.8 & 13.7 & 4.2 & 3.4 & 1.9 & 1.1 & 815.5 & 4.7 & 234.9 \\
\hline & 11.5 & dark grey/silty clay & 40.3 & 13.3 & 4.3 & 3.3 & 1.9 & 1.0 & 841.5 & 5.4 & 225.7 \\
\hline & 15.5 & dark grey/silty clay & 40.6 & 14.6 & 4.3 & 3.8 & 1.6 & 1.2 & 757.9 & 9.3 & 260.0 \\
\hline & 17.5 & dark grey/silty clay & 39.5 & 11.3 & 4.0 & 2.9 & 1.9 & 0.6 & 644.1 & 4.7 & 163.2 \\
\hline & 18.5 & dark grey/silty clay & 39.9 & 13.7 & 3.6 & 3.5 & 1.6 & 1.3 & 1170.0 & 9.9 & 231.7 \\
\hline & 21.5 & dark grey/fine sand & 40.6 & 13.1 & 2.5 & 3.4 & 1.2 & 0.6 & 185.2 & 11.6 & 187.0 \\
\hline & 23.5 & dark grey/fine sand & 40.5 & 12.6 & 2.7 & 3.2 & 1.2 & 0.5 & 189.6 & 9.2 & 190.0 \\
\hline
\end{tabular}

such as Bangladesh (BGS and DPHE, 2001). The amounts of OC and IC in both cores were comparable, and generally less than $0.5 \%$ (Fig. 4).

Main elements of the analyzed sediments according to $\mathrm{XRF}$ analysis were $\mathrm{Si}, \mathrm{Al}, \mathrm{Fe}, \mathrm{K}, \mathrm{Ca}$ and $\mathrm{Mg}$ (Table 2). These results were similar to the previous studies in Bangladesh (Anawar et al., 2003; Swartz et al., 2004). Sulfur and manganese were the minor constituent elements, and their contents were less than 1300 and $300 \mathrm{mg} \mathrm{kg}^{-1}$, respectively. Correlated relations between As with $\mathrm{Fe}\left(r^{2}=0.46, p<0.05\right)$, $\mathrm{Mn}\left(r^{2}=0.58, p<0.05\right)$ and $\mathrm{S}\left(r^{2}=0.78, p<0.05\right)$ were observed in YL6-1, whereas no interrelations among these elements were observed in YL7-1 (Fig. 5).

The HGMS studies were operated specifically to concentrate Fe minerals from the sediments, and these separates exhibited different profiles of $\mathrm{Fe}$ and As in comparison with the untreated samples (without HGMS treatment) (Fig. 4). Among these separates, the average As contents reached 82.2 and $119.4 \mathrm{mg} \mathrm{kg}^{-1}$ with the mean $\mathrm{Fe}$ contents of 12.7 and $15.0 \%$ for YL6-1 and YL7-1, respectively. Arsenic contents in YL6-1 ranged from 50.3 to $90.6 \mathrm{mg} \mathrm{kg}^{-1}$. However, YL7-1 showed the higher As contents, spreading from $100.2 \mathrm{mg} \mathrm{kg}^{-1}$ at the top to $210.7 \mathrm{mg} \mathrm{kg}^{-1}$ at the bottom. In contrast to the samples without HGMS treatment, the As contents in the magnetic fractions increased about tenfold, confirming the As-host ability of $\mathrm{Fe}$ minerals in the sediments.

In addition to determining the quantity of $\mathrm{As}$ and $\mathrm{Fe}$ in the magnetic fractions, the types of $\mathrm{Fe}$ minerals were characterized by HR-XPS, and the results were presented by two
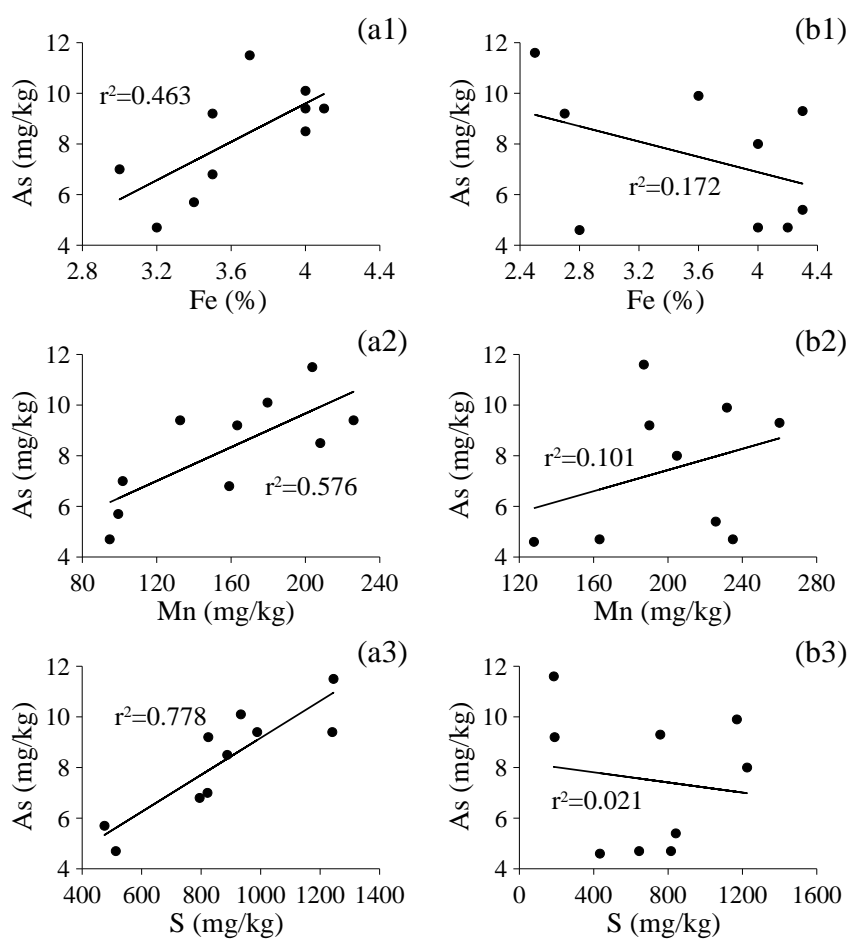

Fig. 5. Relationships of As between Fe, Mn, and $\mathrm{S}$ in the solid phase of (a) YL6-1 and (b) YL7-1. 
curves - (1) the experimental curve after smoothing using the spline method, and (2) the curve of the fitted components (Fig. 6). The iron signal was a doublet because of spin coupling, corresponding to $\mathrm{Fe} 2 \mathrm{p}_{3 / 2}(\mathrm{BE}=706-718 \mathrm{eV})$ and $\mathrm{Fe} 2 \mathrm{p}_{1 / 2}(\mathrm{BE}=723-732 \mathrm{eV})$. The Fe2 $\mathrm{p}_{3 / 2}$ line can be fitted by four components with binding energies of about 709, 712, 714 , and $717 \mathrm{eV}$, respectively (Fig. 6). The primary peak $\left(\mathrm{Fe} 2 \mathrm{p}_{3 / 2}\right)$ at $709.2-709.3 \mathrm{eV}$ was characteristic of $\mathrm{Fe}(\mathrm{II})$ in $\mathrm{FeO}$ compounds (Fig. 6); that at $710.9-711.1 \mathrm{eV}$ was characteristic of $\mathrm{Fe}(\mathrm{III})$ in $\mathrm{Fe}_{2} \mathrm{O}_{3}$ compounds (Fig. 6b, c, e, f); and that at $711.2-712.3 \mathrm{eV}$ was characteristic of $\mathrm{Fe}(\mathrm{III})$ in $\mathrm{FeOOH}$ compounds (Fig. 6a, d). Siderite, Fe-sulfides or glauconite and other Fe-bearing Al-silicates may be present in a coastal groundwater environment. The HR-XPS analysis is not able to recover the signals of the existence of these minerals in the study. All analyzed samples contained both reducing and oxidizing forms of $\mathrm{Fe}$ oxyhydroxides, suggesting the redox cycling of $\mathrm{Fe}$ in the shallow aquifer.

\subsection{Batch experiment of anions effects on As desorption}

The valence of solid As in the selected sediments within the well screen range of YL6-1 $(16 \mathrm{~m})$ and YL7-1 (18 m) for leaching test was determined, comprised of As(III) and $\mathrm{As}(\mathrm{V})$ from XANES spectra. In contrast to the dominance of As(III) in YL6-1, As(V) was dominant in YL7-1, reflecting the complex hydrological process (Fig. 7). Notably, the groundwater EC in YL6 $\left(12129 \mu \mathrm{Scm}^{-1}\right)$ was six times higher than that in YL7 $\left(2039 \mu \mathrm{S} \mathrm{cm}^{-1}\right)$, indicating these two sediment samples are under different aqueous geochemical environments. The kinetics desorption of arsenic from both sediments were assessed by the addition of different competitive anions with various concentration levels (Fig. 8). For sulfate and chloride, even at the highest loading of $1 \mathrm{M}$, no obvious elevated concentration of As was detected within the 75 days of extended experimental duration, implicating the negligible influence derived from seawater infiltration on arsenic desorption. For bicarbonate and phosphate, the desorbed fractions increased rapidly within $24 \mathrm{~h}$, followed by gradual increase, and reached near-equilibrium after about 30 days. Moreover, the increase in arsenic desorption was generally consistent with the elevated anionic concentrations. The predominance of $\mathrm{As}(\mathrm{V})$ in the aqueous phase $(\sim 99 \%)$ assemblage with the mixing of $\mathrm{As}(\mathrm{III})$ and $\mathrm{As}(\mathrm{V})$ as the sedimentary As can be in part attributed to the imposed condition (under atmospheric environment).

For bicarbonate, the leached portions of As varied from 0.46 to $1.79 \mathrm{mgkg}^{-1}$ for YL6-1 and from 0.08 to $0.75 \mathrm{mg} \mathrm{kg}^{-1}$ for YL7-1. As compared with the initial desorption concentration at $0.1 \mathrm{M}$ for YL6-1, the desorption of As in YL7-1 was initiated while amending with $0.01 \mathrm{M}$ of bicarbonate. Only half the amount of As, however, was released in the presence of the highest concentration (1 M; Fig. 8). The greater effect of bicarbonate on YL6-1 than YL7-1 was due to the formation of aqueous As- $\mathrm{HCO}_{3}$ com-

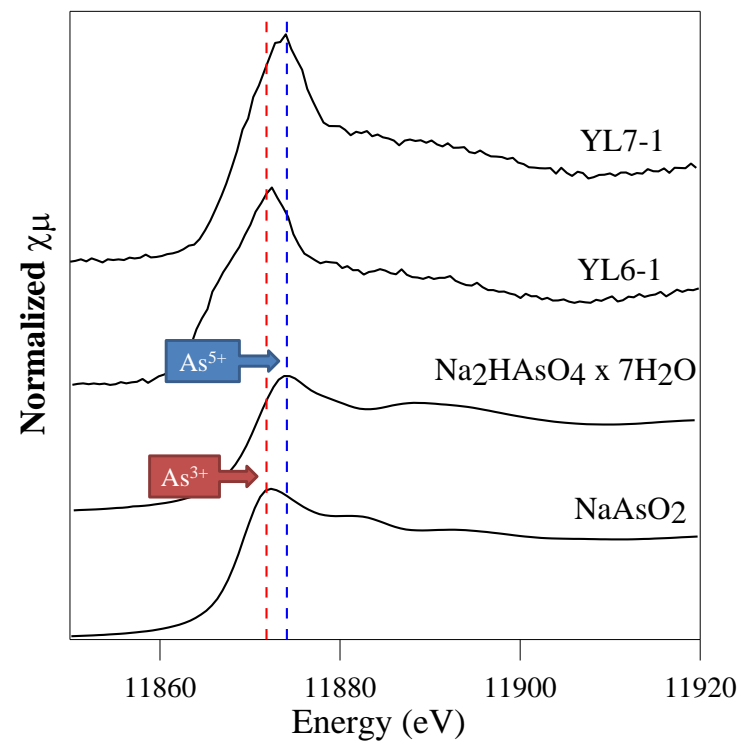

Fig. 6. Curve-fitting data of the $\mathrm{Fe} 2 \mathrm{p}_{3 / 2}$ core level. (a) $13 \mathrm{~m}$ in YL61 , (b) $15 \mathrm{~m}$ in YL6-1, (c) $8 \mathrm{~m}$ in YL7-1, (d) $10 \mathrm{~m}$ in YL7-1, (e) $14 \mathrm{~m}$ in YL7-1, and (f) $21 \mathrm{~m}$ in YL7-1. The solid line represents the experimental curve after smoothing and the dotted lines represent the fitted curve.

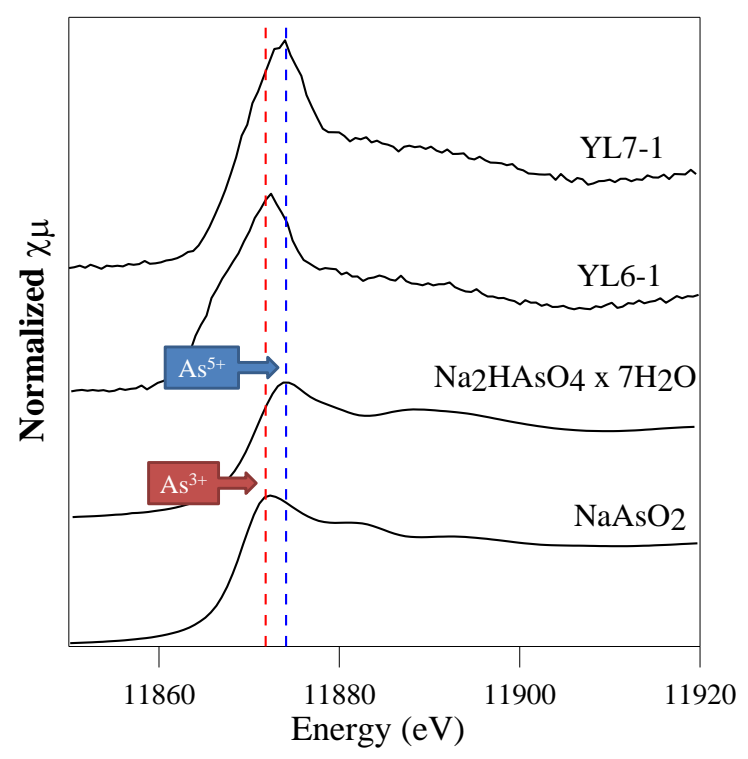

Fig. 7. Normalized As XANES spectra data of the sediments from YL6-1 (16 m) and YL7-1 (18 m) used in the leaching experiments. Referenced $\mathrm{As}^{3+}$ and $\mathrm{As}^{5+}$ standards are $\mathrm{NaAsO}_{2}$ and $\mathrm{Na}_{2} \mathrm{HASO}_{4} \times 7 \mathrm{H}_{2} \mathrm{O}$, respectively.

plexes as well as competitive displacement of arsenic (Apello et al., 2002).

For phosphate, the leaching concentrations of As ranged from 0.91 to $1.83 \mathrm{mg} \mathrm{kg}^{-1}$ for YL6-1 and from 0.90 to $2.72 \mathrm{mg} \mathrm{kg}^{-1}$ for YL7-1. Arsenic release was a function of phosphate added for low phosphate additions, but became 

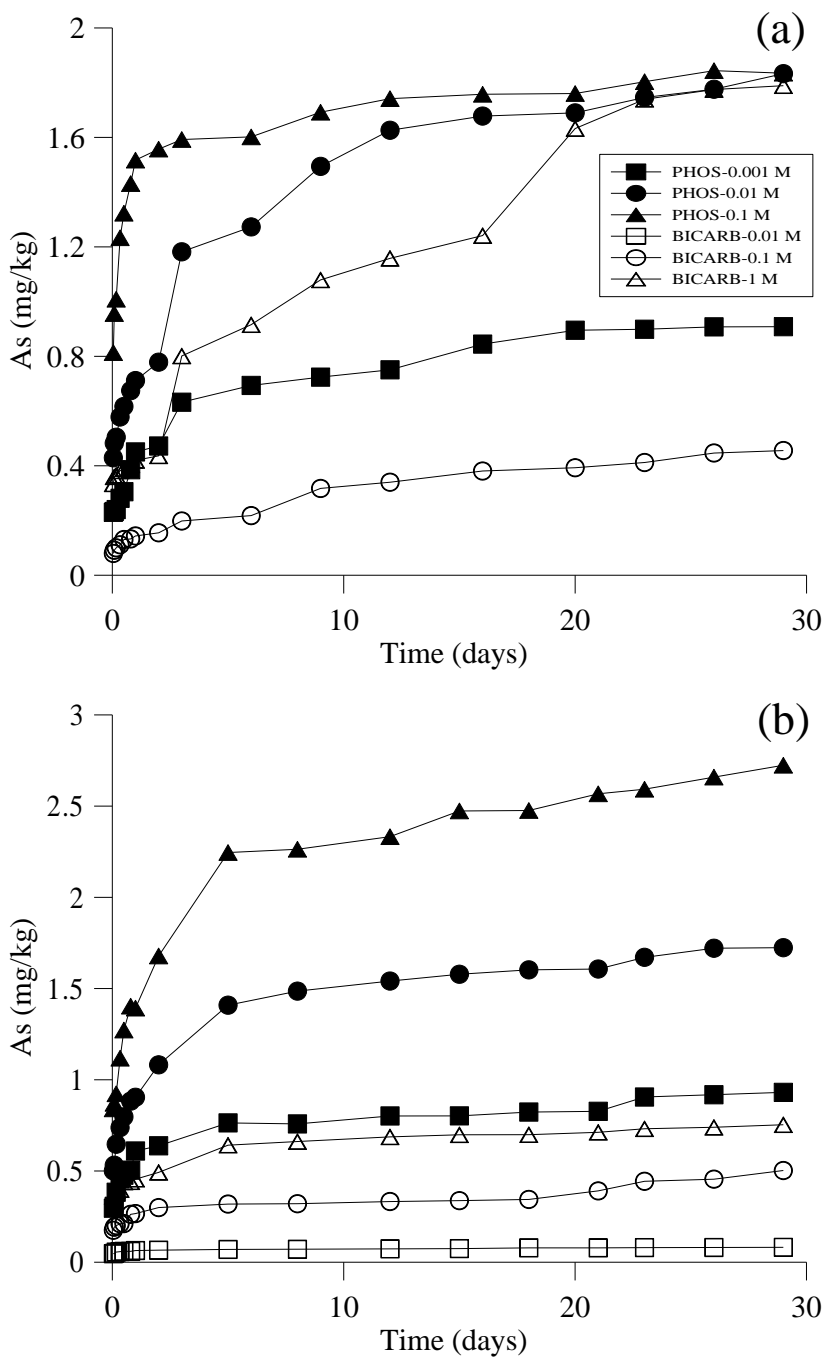

Fig. 8. Time-dependent desorption of arsenic with bicarbonate at $0.01,0.1$, and $1 \mathrm{M}$ and phosphate at $0.001,0.01$, and $0.1 \mathrm{M}$ from (a) YL6-1 and (b) YL7-1.

insensitive at high phosphate addition, particularly for YL61. Between the lowest $(0.001 \mathrm{M})$ and highest $(0.1 \mathrm{M})$ concentrations of phosphate, the fraction of arsenic desorbed increased only twice in magnitude in YL6-1 (Fig. 8a). With respect to YL7-1, the removal of As was proportional to the added anionic concentration (Fig. 8b). Besides, the equilibrium As concentrations observed at sets with $1 \mathrm{M}$ bicarbonate, and to which 0.01 and $0.1 \mathrm{M}$ phosphate were similar in YL6-1, revealed the limitation of leachable As. Consequently, the leaching behaviors were different for the two cores containing either bicarbonate or phosphate. Furthermore, bicarbonate anions caused less desorption of arsenic than phosphate on a molar basis.

\subsection{Numerical modeling of As desorption experiment}

The experimental data of As desorption were modeled with PHREEQC. The four anions $\mathrm{Cl}^{-}, \mathrm{SO}_{4}^{2-}, \mathrm{HCO}_{3}^{-}$and $\mathrm{PO}_{4}^{3-}$ were simulated with the same varied concentrations in the batch experiment using the titration approach (Chen and Anderson, 2002). The initial arsenic contents of 8.5 and $9.9 \mathrm{mg} \mathrm{kg}^{-1}$ in core samples of YL6-1 and YL7-1, respectively, were assumed. The weight of core sample was $0.2 \mathrm{~g}$, and the specific area of the sediment was $15 \mathrm{~m}^{2} \mathrm{~g}^{-1}$ (Maji et al., 2012). The surface complexation model for hydrous ferric oxide (Hfo) developed by Dzombak and Morel (1990) was adopted, of which two types of sites could accommodate all experimental data. These were the "strong" and "weak" sites and labeled as "s" and "w" in Table 3. The weak and strong adsorption site density were 0.005 and 0.2 molesites moleHfo ${ }^{-1}$. The thermodynamic data of $\mathrm{As}^{3+}$, $\mathrm{As}^{5+}, \mathrm{SO}_{4}^{2-}, \mathrm{HCO}_{3}^{-}$, and $\mathrm{PO}_{4}^{3-}$ were listed in Table 3. Notably, no thermodynamic data were available for $\mathrm{Cl}^{-}$surface complexation reactions. A first-order reaction model was proposed to represent the kinetic desorption of As as follows:

$\frac{\mathrm{d} C}{\mathrm{~d} t}=-k_{1} C$,

where $C$ is the arsenic concentration, $k_{1}$ is the kinetic rate constant and is set to 0.05 and 0.1 for $\mathrm{As}^{3+}$ and $\mathrm{As}^{5+}$, respectively (Maji et al., 2007, 2011, 2013).

The simulated time-dependent arsenic desorption of YL6-1 and YL7-1 at various anionic $\left(\mathrm{PO}_{4}^{3-}, \mathrm{HCO}_{3}^{-}, \mathrm{SO}_{4}^{2-}\right.$ and $\mathrm{Cl}^{-}$) concentrations are shown in Fig. 9. The simulated arsenic desorption curves and the amount of arsenic desorption of YL7-1 and YL6-1 by $\mathrm{PO}_{4}^{2-}$ were close to the experimental results, but were much less than the experimental data from $\mathrm{HCO}_{3}^{-}$. The laboratory arsenic desorption experiment used the in situ core samples contain both organic carbon and inorganic carbon. These carbons can be converted and utilized by microbes as energy sources and promote the reductive dissolution of iron oxyhydroxide accompanying the desorption of arsenic. Moreover, dissolved As can combine with dissolved organic matter, preventing adsorptive interaction between As and flocculated iron oxide in saline water (Waslenchuk and Windom, 1978). The simulated model considered the pure inorganic adsorption reaction, which did not include the desorption enhanced by the microbial reaction and thus greatly underestimated the amount of arsenic desorption. For sulfate and chloride, the effects on the amount of arsenic desorption are minor, which agree with the batch experimental results (Su and Pulse, 2001; Radu et al., 2005; Halim et al., 2009; Maji et al., 2013).

Notably, the sulfate ion slightly promoted the arsenic desorption, whereas the chloride ion yielded less desorption of arsenic, which may mildly reduce the aqueous arsenic concentrations. The comparison of the experimental and 
Table 3. Thermodynamic data of surface complexation constants for arsenite, arsenate, phosphate, sulfate and carbonate (Allison et al., 1990; van Geen et al., 2004).

\begin{tabular}{|c|c|}
\hline Adsorption reaction & $\log \mathrm{K}$ \\
\hline \multicolumn{2}{|l|}{ Arsenite } \\
\hline $\mathrm{Hfo}{ }_{-} \mathrm{sOH}+\mathrm{H}_{3} \mathrm{AsO}_{3}=\mathrm{Hfo} \_\mathrm{sH}_{2} \mathrm{AsO}_{3}+\mathrm{H}_{2} \mathrm{O}$ & 5.41 \\
\hline $\mathrm{Hfo} \_\mathrm{wOH}+\mathrm{H}_{3} \mathrm{AsO}_{3}=\mathrm{Hfo} \_\mathrm{wH}_{2} \mathrm{AsO}_{3}+\mathrm{H}_{2} \mathrm{O}$ & 5.41 \\
\hline \multicolumn{2}{|l|}{ Arsenate } \\
\hline Hfo_s $\mathrm{sOH}+\mathrm{H}_{3} \mathrm{AsO}_{4}=\mathrm{Hfo} \_\mathrm{sH}_{2} \mathrm{AsO}_{4}+\mathrm{H}_{2} \mathrm{O}$ & 8.61 \\
\hline $\mathrm{Hfo}_{-} \mathrm{wOH}+\mathrm{H}_{3} \mathrm{AsO}_{4}=\mathrm{Hfo}_{-} \mathrm{wH}_{2} \mathrm{AsO}_{4}+\mathrm{H}_{2} \mathrm{O}$ & 8.61 \\
\hline $\mathrm{Hfo}_{-} \mathrm{sOH}+\mathrm{H}_{3} \mathrm{AsO}_{4}=\mathrm{Hfo} \_\mathrm{sHAsO}_{4}^{-}+\mathrm{H}_{2} \mathrm{O}+\mathrm{H}^{+}$ & 2.81 \\
\hline $\mathrm{Hfo} \_\mathrm{wOH}+\mathrm{H}_{3} \mathrm{AsO}_{4}=\mathrm{Hfo}_{-} \mathrm{wHAsO}_{4}^{-}+\mathrm{H}_{2} \mathrm{O}+\mathrm{H}^{+}$ & 2.81 \\
\hline $\mathrm{Hfo}_{-} \mathrm{sOH}+\mathrm{H}_{3} \mathrm{AsO}_{4}=\mathrm{Hfo} \_\mathrm{sOHAsO} \mathrm{H}_{4}^{3-}+3 \mathrm{H}^{+}$ & -10.12 \\
\hline $\mathrm{Hfo}_{-} \mathrm{wOH}_{+}+\mathrm{H}_{3} \mathrm{AsO}_{4}=\mathrm{Hfo}_{-} \mathrm{wOHAsO}_{4}^{3-}+3 \mathrm{H}^{+}$ & -10.12 \\
\hline \multicolumn{2}{|l|}{ Phosphate } \\
\hline $\mathrm{Hfo} \_\mathrm{sOH}+\mathrm{PO}_{4}^{3-}+3 \mathrm{H}^{+}=\mathrm{Hfo} \_\mathrm{sH}_{2} \mathrm{PO}_{4}+\mathrm{H}_{2} \mathrm{O}$ & 31.29 \\
\hline $\mathrm{Hfo} \_\mathrm{wOH}+\mathrm{PO}_{4}^{3-}+3 \mathrm{H}^{+}=\mathrm{Hfo} \_\mathrm{wH}_{2} \mathrm{PO}_{4}+\mathrm{H}_{2} \mathrm{O}$ & 31.29 \\
\hline $\mathrm{Hfo} \_\mathrm{sOH}+\mathrm{PO}_{4}^{3-}+2 \mathrm{H}^{+}=\mathrm{Hfo} \_\mathrm{sHPO}_{4}^{-}+\mathrm{H}_{2} \mathrm{O}$ & 25.39 \\
\hline $\mathrm{Hfo}_{-} \mathrm{wOH}+\mathrm{PO}_{4}^{3-}+2 \mathrm{H}^{+}=\mathrm{Hfo}_{-} \mathrm{wHPO}_{4}^{-}+\mathrm{H}_{2} \mathrm{O}$ & 25.39 \\
\hline $\mathrm{Hfo}_{-} \mathrm{sOH}+\mathrm{PO}_{4}^{3-}+\mathrm{H}^{+}=\mathrm{Hfo} \_\mathrm{PO}_{4}^{2-}+\mathrm{H}_{2} \mathrm{O}$ & 17.72 \\
\hline $\mathrm{Hfo}_{-} \mathrm{wOH}+\mathrm{PO}_{4}^{3-}+\mathrm{H}^{+}=\mathrm{Hfo} \_\mathrm{wPO}_{4}^{2-}+\mathrm{H}_{2} \mathrm{O}$ & 17.72 \\
\hline \multicolumn{2}{|l|}{ Sulfate } \\
\hline $\mathrm{Hfo}_{-} \mathrm{wOH}+\mathrm{SO}_{4}^{2-}+\mathrm{H}^{+}=\mathrm{Hfo} \_\mathrm{wSO}_{4}^{-}+\mathrm{H}_{2} \mathrm{O}$ & 7.78 \\
\hline $\mathrm{Hfo}_{-} \mathrm{wOH}+\mathrm{SO}_{4}^{2-}=\mathrm{Hfo}_{-} \mathrm{wOHSO}_{4}^{2-}$ & 0.79 \\
\hline \multicolumn{2}{|l|}{ Carbonate } \\
\hline $\mathrm{Hfo} \_\mathrm{wOH}+\mathrm{CO}_{3}^{2-}+\mathrm{H}^{+}=\mathrm{Hfo} \_\mathrm{wCO}_{3}^{-}+\mathrm{H}_{2} \mathrm{O}$ & 12.56 \\
\hline $\mathrm{Hfo}_{-} \mathrm{wOH}+\mathrm{CO}_{3}^{2-}+2 \mathrm{H}^{+}=\mathrm{Hfo}_{-} \mathrm{wHCO}_{3}+\mathrm{H}_{2} \mathrm{O}$ & 20.62 \\
\hline
\end{tabular}

simulated amount of As desorption by $\mathrm{PO}_{4}^{3-}$ and $\mathrm{HCO}_{3}^{-}$of YL6-1 and YL7-1 after 30 days are given in Table 4.

\section{Discussion}

\subsection{Water quality related to As enrichment}

Shallow groundwater aquifer are generally salinized by seawater flooding and salt water percolation from fish pond farming. Seawater intrusion shows a small effect on aquifer salinization. Arsenic concentrations did not correlate with the well depth and the EC values, suggesting that the effects of saline water on the arsenic release were complex. Among the collected water samples, high As concentration with increasing levels of $\mathrm{HCO}_{3}^{-}, \mathrm{NH}_{4}^{+}$and $\mathrm{Fe}$ concentrations, coupled with high $\mathrm{pH}(\mathrm{pH}=8)$ typically represented the onset of reductive dissolution of $\mathrm{Fe}$ oxyhydroxides concurrent with the mobility of As. Poor correlation between dissolved As and Fe concentrations in groundwater indeed reflect the complexity of geochemical reactions in the subsurface (Nickson et al., 2000; Harvey et al., 2002) and in part can be attributed to the mixing with saline water. Sulfate in saline groundwater
Table 4. Comparison of experimental and simulated amount of As desorption from core samples after 30 days.

\begin{tabular}{llccl}
\hline Anion & $\begin{array}{l}\text { Concentration } \\
\left(\mathrm{mole} \mathrm{L}^{-1}\right)\end{array}$ & $\begin{array}{c}\text { Core } \\
\text { type }\end{array}$ & $\begin{array}{c}\text { Measured } \\
\text { desorption } \\
\left(\mathrm{mg} \mathrm{kg}^{-1}\right)\end{array}$ & $\begin{array}{l}\text { Simulated } \\
\text { desorption } \\
\left(\mathrm{mg} \mathrm{kg}^{-1}\right)\end{array}$ \\
\hline \multirow{2}{*}{0.1} & YL6-1 & 1.8 & 2.41 \\
$\mathrm{PO}_{4}^{3-}$ & \multirow{2}{*}{0.01} & YL7-1 & 2.8 & 2.8 \\
& & YL6-1 & 1.75 & 0.74 \\
& \multirow{2}{*}{0.001} & YL6-1 & 1.5 & 0.86 \\
& & YL7-1 & 0.8 & 0.031 \\
& \multirow{2}{*}{1} & YL6-1 & 1.7 & 0.036 \\
& & YL7-1 & 0.7 & 0.021 \\
$\mathrm{HCO}_{3}^{-} 0.1$ & YL6-1 & 0.4 & 0.016 \\
& \multirow{2}{*}{0.01} & YL7-1 & 0.5 & 0.019 \\
& & YL6-1 & $<0.1$ & 0.011 \\
& & YL7-1 & 0.1 & 0.012 \\
\hline
\end{tabular}

may act as an electron acceptor and promote precipitation of sulfide minerals. Formation of sulfide minerals restrained the liberated As in the anaerobic environment. The redox cyclic interactions of iron and sulfur resulted in the low-As and high-Fe concentrations in saline water (Wang et al., 2011). A moderate correlation of aqueous As was only observed with DOC $\left(r^{2}=0.41, p<0.05\right)$, as also indicated by Harvey et al. (2002). The existence of organic carbon can trigger microbial activity, followed by the formation of reducing conditions and release of As via chemical and biological processes in the subsurface formation (Harvey et al., 2002; Sutton et al., 2009; Halim et al., 2009). Accordingly, these characteristics were consistent with the microbially mediated release of As via the reductive dissolution of iron oxyhydroxides (Nickson et al., 2000; McArthur et al., 2001; Harvey et al., 2002; Rowland et al., 2008; Hasan et al., 2009; Nath et al., 2009).

Further assessment of groundwater quality was conducted on the basis of a domestic water source standard for As in Taiwan, $50 \mu \mathrm{g} \mathrm{L}-1$. For the wells with As above $50 \mu \mathrm{g} \mathrm{L}-1$, positive correlations were observed between As and $\mathrm{Fe}$ and DOC $\left(r^{2}=0.46\right.$ and $0.41, p<0.05$, respectively). The other group wells, with As below $50 \mu \mathrm{gL} \mathrm{L}^{-1}$, showed a poor correlation between $\mathrm{As}$ and $\mathrm{Fe}$, even with DOC $\left(r^{2}<0.01\right)$. Correlations among As, $\mathrm{Fe}$ and DOC concentrations were only significant via the categorization of As concentration with $50 \mu \mathrm{gL}^{-1}$, implicating that a threshold value of As concentration served as an indicator for identifying the active proceeding of reductive dissolution of As-bearing oxyhydroxides in the study area. 

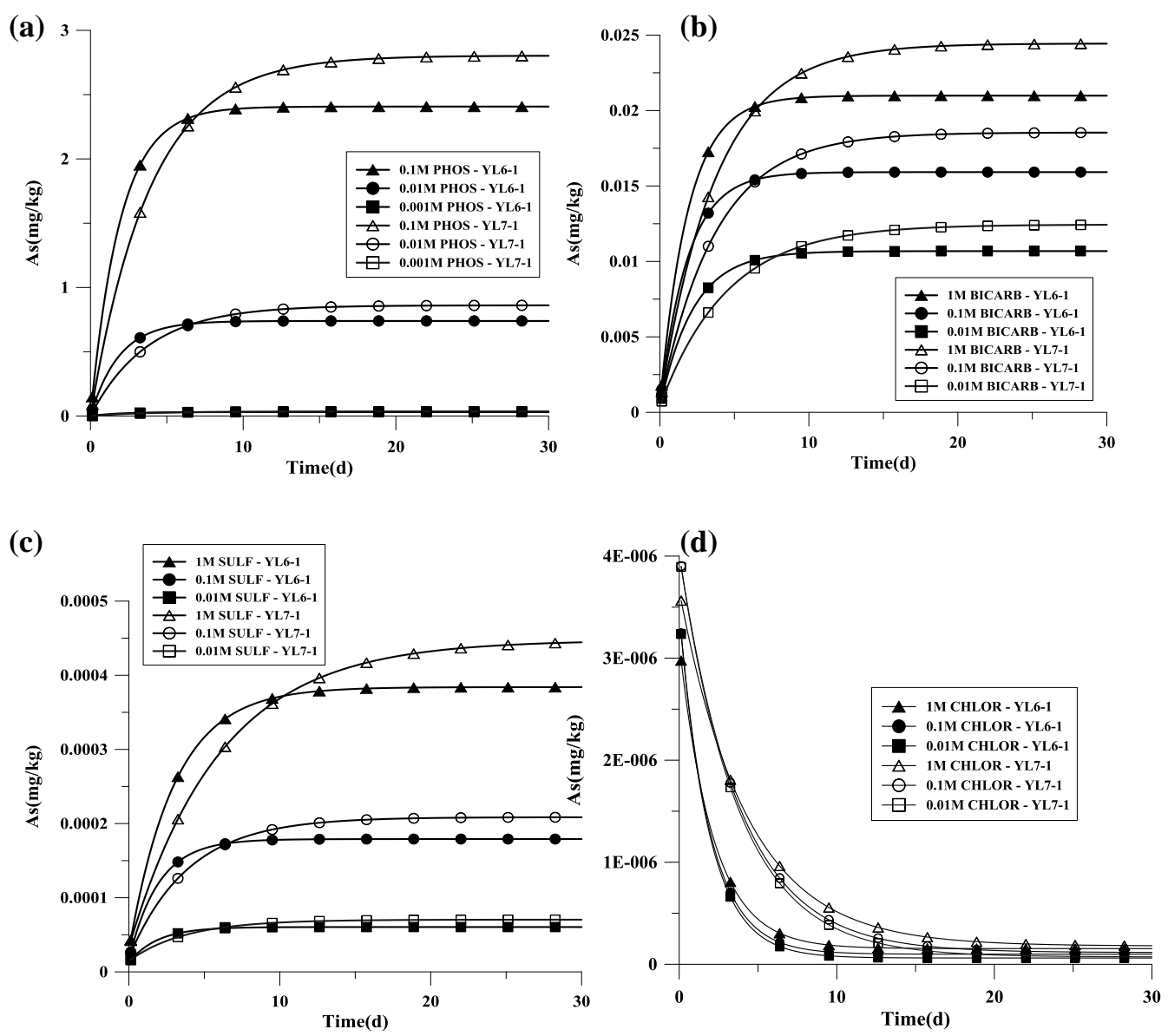

Fig. 9. Simulated time-dependent As desorption of YL6-1 and YL7-1 at various anionic concentrations (a) $\mathrm{PO}_{4}^{3-},(\mathbf{b}) \mathrm{HCO}_{3}^{-},(\mathbf{c}) \mathrm{SO}_{4}^{2-}$, and (d) $\mathrm{Cl}^{-}$.

\subsection{Implication from solid profiles of $\mathrm{As}, \mathrm{Fe}$ and $\mathrm{OC}$}

In a previous study (Liu et al., 2003a) proposed that the quantity of As contents in the sediments was concentrated in the clay samples that were deposited during the Holocene transgression. Actually, the "clay minerals" fractionated from sediments, comprised of magnetic and non-magnetic fractions, were the main pool for As in this area. Irrespective of the poor relationship between As and Fe among the untreated sediments, a significant and positive correlation was observed in the clay fractions $\left(r^{2}=0.50, p<0.05\right)$. The direct source of As in groundwater is believed to be the chemically active As fraction in the sediments, i.e., Fe oxyhydroxides in this area (Lu et al., 2010). Hence, the distinct difference of As contents within the screen range of two boreholes, particularly for the magnetic fraction, can be a potential factor affecting the heterogeneous distribution of As concentrations in the groundwater.

In general, the distribution of major and trace elements in sediment was controlled by various factors such as sediment texture, source-rock mineralogy and geochemical processes (Abraham, 1998). According to the analytical data, although these two cores exhibited different soil color and types, average As and Fe contents for YL6-1 and YL7-1 were comparable (Table 2). The concomitant but gradual decrease of solid As, $\mathrm{Fe}$ and $\mathrm{OC}$ in the untreated samples (without HGMS treatment) of both boreholes was observed within the screen range (Fig. 4). These geochemical profiles provided the direct evidence for the pathway relevant to the microbialmediated reductive dissolution of $\mathrm{Fe}$ minerals with a concurrent decrease of OC contents, despite the variation of the trends that were only moderate.

\subsection{Effects of salination and anionic competition}

Groundwater quality at the coastal shallow aquifer in this area was generally characterized as salination and As contamination (Liu et al., 2003b; Wang et al., 2007; Lu et al., 2010, 2011). In this study, saline water samples (Group 4) were mainly distributed in the shallow depth and contained higher As concentration than other types. Saline water intrusion provided excessive amounts of competition ions, such as $\mathrm{Cl}^{-}$and $\mathrm{SO}_{4}^{2-}$ (Kim et al., 2000; Appelo et al., 2002). However, no obvious evidence showed a direct connection 
between salination and As contamination in the groundwater quality data, leaching experiment or numerical simulations. The competitive effect of salination on the motivation of As mobility has been suggested (Keon et al., 2001), but it contributed only minor portion of As concentration or the batch experiments. However, the isotopic analyses show that the high enrichment of ${ }^{34} \mathrm{~S}_{\left[\mathrm{SO}_{4}\right]}$ and ${ }^{18} \mathrm{O}_{\left[\mathrm{SO}_{4}\right]}$ in saline groundwater, caused by the microbial-mediated reaction of sulfate and high ${ }^{18} \mathrm{O}$ enrichment factor $\left(\epsilon_{\left[\mathrm{SO}_{4}-\mathrm{H}_{2} \mathrm{O}\right]}\right)$, suggests that sulfur disproportionation is also an important process during the reductive dissolution of As-containing iron oxyhydroxides (Kao et al., 2011). Limited co-precipitation of ionsulfide increased the rate of As liberation under anaerobic conditions.

Since the high-arsenic groundwater at the Choushui River alluvial fan commonly has bicarbonate as the major anion, the role of competitive adsorption of bicarbonate should not be neglected. According to the results of batch experiments of Kim et al. (2000), bicarbonate solutions leached the greatest quantity of arsenic $\left(1.2-1.6 \mathrm{mg} \mathrm{kg}^{-1}\right)$ from the aquifer materials (with a total arsenic concentration of $24.6 \mathrm{mg} \mathrm{kg}^{-1}$ ), as compared to other solutions. Similar results were also observed herein. However, Radu et al. (2005) reported that the carbonate ions had a small effect on the competition with As for iron oxide-coated sand, and resulted in only a slight decrease in As adsorption. The cause of the major difference in the carbonate ions' effect on the As desorption is that both Kim et al. (2000) and our study used the in situ core sample as the adsorbent, whereas Radu et al. (2005) used the synthetic iron-oxide-coated sand. The in situ core sediment contained OC, IC and microbials which can biogeochemically enhance the Fe oxyhydroxides dissolution and As desorption (Liao et al., 2011). Our numerical simulation results, which only considered inorganic competition by carbonate ions, also show much less desorption of As compared to the laboratory batch data. The vital role of microbial-mediated desorption and mobilization of As in the groundwater is clearly evident. Varied equilibrium concentration between different amending sediments can be ascribed to the sources of the adsorption host (Fuller et al., 1993; Wang et al., 2004). Moreover, desorption of arsenic by bicarbonate was easily assessable at YL7-1, but reached maximum values at YL6-1. Due to the observation of higher bicarbonate concentration than phosphate in the in situ environment, the contribution of bicarbonate to the total arsenic leaching is greater than phosphate, especially for YL6-1.

Compared to bicarbonate, there was a significant elevation of arsenic concentration as phosphate levels increased. For YL6-1, this suggests that the desorption rate was high at low phosphate concentration. In contrast, the proportional increase of As was concurrent with the imposed phosphate concentration in YL7-1 (Fig. 8). Different valences of dominant As species in the sediment explained the desorption trends of phosphate between these sets (Fig. 7). Arsenate is generally susceptible to the presence of elevated phosphate concentrations. The strong ability of phosphate to inhabit the arsenate adsorption on iron oxyhydroxides has been verified (Dixit and Hering, 2003). The competition between $\mathrm{PO}_{4}^{3-}$ and $\mathrm{As}(\mathrm{OH})_{3}$ is likely to be less significant than the $\mathrm{PO}_{4}^{3-}$ and $\mathrm{AsO}_{4}^{3-}$ (Smedley and Kinniburgh, 2002). Moreover, the YL7-1 solutions reached near-equilibrium faster than the YL6-1 solutions, which could reflect their lower particle size and its contribution to intra-particle diffusion (Ghosh et al., 2006).

\section{Conclusions}

To comprehend the hydrogeochemical characteristics of Ascontaminated saline aquifers in the coastal area of the southern Choushui River alluvial, detailed analyses were conducted as a function of lithology, mineralogy, geochemistry and hydrochemistry. Leaching experiments and numerical simulations were also conducted to assess the competitive effect of various anions on As release. Groundwater was mostly $\mathrm{NaCl}$ - or $\mathrm{Na}-\mathrm{Mg}-\mathrm{HCO}_{3}$-type, dependent on the depth in the area. Saline water type prevailed in the uppermost aquifers and non-saline water was in the lower aquifer. High levels of As concentrations were found in both the uppermost and lower aquifers. No direct evidence revealed the correlation among salination, As concentration and well depth.

The analytical results evidenced that the clay fraction, especially for the magnetic fraction, acted as the principal pool of As in the sediment. Significant correlations of As with DOC and Fe concentrations were only observed in groundwaters with a threshold of elevated As concentrations $\left(>50 \mu \mathrm{gL}^{-1}\right)$ which can serve as an indicator in the saline aquifer for the active proceeding of reductive dissolution of $\mathrm{Fe}$ oxyhydroxides with microbially mediated degradation of organic matter. Concurrent decrease of solid As, $\mathrm{Fe}$ and OC contents observed within the well screen area further supported the presence of actively reductive dissolution of Asbearing Fe minerals. The leaching behaviors of As among the posited sediments were closely dependent on its solid valence and the kinds of competitive anions from the XANES and batch experimental data. Contrary to YL6-1 as the dominance of $\mathrm{As}(\mathrm{III})$ in the solid phase, the dominant $\mathrm{As}(\mathrm{V})$ in the sediment of YL7-1 was more liable to phosphate addition. Experimental and numerical results showed that the contributions of $\mathrm{Cl}^{-}$and $\mathrm{SO}_{4}^{2-}$ to arsenic desorption were low as compared to those of bicarbonate and phosphate. Although phosphate had a higher competitive potential than bicarbonate on an equal molar concentration of anions, the prevalence of bicarbonate and microbial-mediated reactions in the subsurface contributed greater amounts of dissolved As than phosphate. Collectively, the effect of saline water on the As release to groundwater is mild in the coastal aquifer. 
Acknowledgements. The authors would like to thank the National Synchrotron Radiation Research Center for providing XANES analyses and the National Science Council of the Republic of China, Taiwan, for financially supporting this research under Contract no. NSC-95-2313-B-002-050-MY3.

Edited by: A. D. Reeves

\section{References}

Abraham, J.: Spatial distribution of major and trace elements in shallow reservoir sediments: an example from Lake Waco, Texas, Environ. Geol., 36, 349-363, 1998.

Allison, J. D., Brown, D. S., and Novo-Gradac K. J.: MINTEQA2/PRODEFA2 - A Geochemical Assessment Model for Environmental Systems, US Environmental Protection Agency, Athens, Georgia, 1990.

Anawar, H. M., Akai, J., Komaki, K., Terao, H., Yoshioka, T., Ishizuka, T., Safiullah, S., and Kato, K.: Geochemical occurrence of arsenic in groundwater of Bangladesh: sources and mobilization processes, J. Geochem. Explor., 77, 109-131, 2003.

APHA: Standard Methods for the Examination of Water and Waste Water, 20th Edn., American Public Health Association, Washington, DC, 413-426, 1998.

Appelo, C. A. J., Van der Weiden, M. J. J., Tournassat, C., and Charlet, L.: Surface complexation of ferrous iron and carbonate on ferrihydrite and the mobilization of arsenic, Environ. Sci. Technol., 36, 3096-3103, 2002.

Berg, M., Trang, P. T. K., Stengel, C., Buschmann, J., Viet, P. H., Van Dan N., Giger, W., and Stüen, D.: Hydrological and sedimentary controls leading to arsenic contamination of groundwater in the Hanoi Area, Vietnam: The impact of iron-arsenic ratios, peat, river bank deposits, and excessive groundwater abstraction, Chem. Geol., 249, 91-112, 2008.

BGS and DPHE: Arsenic contamination of groundwater in Bangladesh, edited by: Kinniburgh, D. G. and Smedley, P. L., 4 volumes, British Geological Survey Report, British Geological Survey, Keyworth, 2001.

Chen, W. F. and Liu, T. K.: Dissolved oxygen and nitrate of groundwater in Choushui Fan-Delta, western Taiwan, Environ. Geol., 44, 731-737, 2003.

Chen, Z. and Anderson, G.: Environmental Applications of Geochemical Modeling, Cambridge Press, 284 pp., 2002.

Dixit, S. and Hering, J. G.: Comparison of $\operatorname{arsenic}(\mathrm{V})$ and arsenic(III) sorption onto iron oxide minerals: Implications for arsenic mobility, Environ. Sci. Technol., 37, 4182-4189, 2003.

Drahota, P., Rohovec, J., Filippi, M., Mihaljevič, M., Rychlovský, P., Červený, V., and Pertold, Z.: Mineralogical and geochemical controls of arsenic speciation and mobility under different redox conditions in soil, sediment and water at the Mokrsko-West gold deposit, Czech Republic, Sci. Total. Environ., 407, 3372-3384, 2009.

Dzombak, D. A. and Morel, F. M. M.: Surface Complexation Modeling: Hydrous Ferric Oxide, John Wiley \& Sons, New York, 1990.

Fuller, C. C., Davis, J. A., and Waychunas, G. A.: Surface chemistry of ferrihydrite: Part 2. Kinetics of arsenate adsorption and coprecipitation, Geochim. Cosmochim. Ac., 57, 2271-2282, 1993.
Ghosh, A., Eduardo Saez, A., and Ela, W.: Effect of pH, competitive anions and NOM on the leaching of arsenic from solid residuals, Sci. Total Environ., 363, 46-59, 2006.

Halim, M. A., Majumder, R. K., Nessa, S. A., Bangiroshiro, H., Uddin, Y., M. J., Shimada, J., and Jinno, K.: Hydrogeochemistry and arsenic contamination of groundwater in the Ganges Delta Plain, Bangladesh, J. Hazard. Mater., 164, 1335-1345, 2009.

Harvey, C. F., Swartz, C. H., Badruzzaman, A. B. M., Keon-Blute, N., Niedan, V., Brabander, D., Oates, P. M., Ashfaque, K. N., Islam, S., Hemond, H. F., and Ahmed, M. F.: Arsenic mobility and groundwater extraction in Bangladesh, Science, 298, 16021606, 2002.

Hasan, M. A., Bhattacharya, P., Sracek, O., Ahmed, K. M., von Bromssen, M., and Jacks, G.: Geological controls on groundwater chemistry and arsenic mobilization: Hydrogeochemical study along an E-W transect in the Meghna basin, Bangladesh, J. Hydrol., 378, 105-118, 2009.

Huang, C. Y.: Foraminiferal analysis and stratigraphic correlation on the subsurface geology of the Choushuichi alluvial fan, in: Conf. on Groundwater and Hydrogeology of Choushui River Alluvial Fan, Taipei, Taiwan, 8-9 February 1996, Water Resources Bureau, Taipei, 5-66, 1996.

Huang, Y. K., Lin, K. H., Chen, H. W., Chang, C. C., Liu, C. W., Yang, M. H., and Hsueh, Y. M.: As species contents at aquaculture farm and in farmed mouthbreeder (Oreochromis mossambicus) in BFD hyperendemic areas, Food Chem. Toxicol., 41, 1491-1500, 2003.

Jackson, M. L.: Soil Chemical Analysis, Advanced Course, 2nd Edn., University of Wisconsin, Madison, WI, USA, 1979.

Kao, Y. H., Wang, S. W., Liu, C. W., Wang, P. L., Wang, C. H., and Maji, S. K.: Biogeochemical cycling of arsenic in coastal salinized aquifers: Evidence from sulfur isotope study, Sci. Total Environ., 409, 4818-4830, 2011.

Keon, N. E., Swartz, C. H., Brabander, D. J., Harvey, C., and Hemond, H. F.: Validation of an arsenic sequential extraction method for evaluating mobility in sediments, Environ. Sci. Technol., 35, 2778-2784, 2001.

Kim, M. J., Nriagu, J., and Haack, S.: Carbonate ions and arsenic dissolution by groundwater, Environ. Sci. Technol., 34, 3094 3100, 2000.

Liao, V. H. C., Chu, Y. J., Su, Y. C., Lin, P. C., Hwang, Y. H., Liu, C. W., Liao, C. M., Chang, F. J., and Yu, C. W.: Assessing the mechanisms controlling the mobilization of arsenic in the arsenic contaminated shallow alluvial aquifer in the blackfoot disease endemic area, J. Hazard. Mater., 197, 397-403, 2011.

Liu, C. W., Lin, K. H., and Kuo, Y. M.: Application of factor analysis in the assessment of groundwater quality in a blackfoot disease area in Taiwan, Sci. Total Environ., 313, 77-89, $2003 \mathrm{a}$.

Liu, C. W., Lin, K. H., Chen, S. Z., and Jang, C. S.: Aquifer Salinization in the Yun-Lin Coastal Area, Taiwan, J. Am. Water Resour. As., 39, 817-827, 2003b.

Liu, C. W., Wang, S. W., Jang, C. S., and Lin, K. H.: Occurrence of arsenic in ground water in the Choushui River alluvial fan, Taiwan, J. Environ. Qual., 35, 68-75, 2006.

Lu, K. L., Liu, C. W., Wang, S. W., Jang, C. S., Lin, K. H., Liao, V. H. C., Liao, C. M., and Chang, F. J.: Primary sink and source of geogenic arsenic in sedimentary aquifers in the southern Choushui River alluvial fan, Taiwan, Appl. Geochem., 25, 684-695, 2010. 
Lu, K. L., Liu, C. W., Wang, S. W., Jang, C. S., Lin, K. H., Liao, V. H. C., Liao, C. M., and Chang, F. J.: Assessing the characteristics of groundwater quality of arsenic contaminated aquifers in the blackfoot disease endemic area, J. Hazard. Mater., 185, 1458-1466, 2011.

Maji, S. K., Pal, A., Pal, T., and Adak, A.: Sorption kinetics of arsenic on laterite soil in aqueous medium, J. Environ. Sci. Heal.A, 42, 989-996, 2007.

Maji, S. K., Kao, Y. M., and Liu, C. W.: Arsenic removal from real arsenic-bearing groundwater by adsorption on iron-oxide-coated natural rock (IOCNR), Desalination, 280, 72-79, 2011.

Maji, S. K., Kao, Y. H., Wang, C. J., Lu, G. S., Wu, J. J., and Liu, C. W.: Fixed bed adsorption of As(III) on iron-oxide-coated natural rock (IOCNR) and application to real arsenic-bearing groundwater, Chem. Eng. J., 203, 285-293, 2012.

Maji, S. K., Wang, S. W., and Liu, C. W.: Arsenate removal from aqueous media on iron-oxide-coated natural rock (IOCNR): a comprehensive batch study, Desalination Water Treat., 51, 77757790, doi:10.1080/19443994.2013.794551, 2013.

Mandal, B. K., Chowdhury, T. R., Samanta, G., Basu, G. K., Chowdhury, P. P., Chanda, C. R., Lodh, D., Karan, N. K., Dhar, R. K., Tamil, D. K., Das, D., Saha, K. C., and Chakrabort, D.: Arsenic in groundwater in seven districts of West Bengal, India-The biggest arsenic calamity in the world, Curr. Sci., 70, 976-986, 1996.

Matthess, G.: The Properties of Groundwater, translated by: Harvey, J. C., Wiley, New York; 406 pp., 1982.

McArthur, J. M., Ravenscroft, P., Safiulla, S., and Thirlwall, M. F.: Arsenic in groundwater: Testing pollution mechanisms for sedimentary aquifers in Bangladesh, Water Resour. Res., 37, 109117,2001

Mukherjee, A. and Fryar, A. E.: Deeper groundwater chemistry and geochemical modeling of the arsenic affected western Bengal basin, West Bengal, India, Appl. Geochem., 23, 863-894, 2008.

Nath, B., Chakraborty, S., Burnol, A., and Stuben, D.: Mobility of arsenic in the sub-surface environment: An integrated hydrogeochemical study and sorption model of the sandy aquifer materials, J. Hydrol., 364, 236-248, 2009.

Nickson, R. T., McArthur, J. M., Ravenscroft, P., Burgess, W. G., and Ahmed, K. M.: Mechanism of arsenic release to groundwater, Bangladesh and West Bengal, Appl. Geochem., 15, 403-413, 2000.

Parkurst, D. L. and Appelo, C. A. J.: User's guide to PHREEQC (version 2): a computer program for speciation, reaction path, 1D transport, and inverse geochemical calculation, US Geol Surv Water Resour Inv Rep 99-4259, 312 pp., 1999.

Radu, T., Subacz, J. L., Phillippi, J. M., and Barnett, M. O.: Effect of dissolved carbonate on arsenic adsorption and mobility, Environ. Sci. Technol., 39, 7875-7882, 2005.

Ravel, B. and Newville, M.: ATHENA, ARTEMIS, HEPHAESTUS: data analysis for X-ray absorption spectroscopy using IFEFFIT, J. Synchrotron Radiat., 12, 537-541, 2005.

Ravenscroft, P., Brammer, H., and Tichards, K.: Arsenic Pollution: A Global Synthesis, Wiley-Blackwell, Chichester UK, 588 pp., 2009.

Rodriguez-Lado, L., Polya, D. A., Winkel, L., Berg, M., and Hegan, A.: Modelling arsenic hazard in groundwater in Cambodia: a geostatistical approach using ancillary data, Appl. Geochem., 23, 3009-3018, 2008.
Rowland, H. A. L., Gault, A. G., Lythgoe, P., and Polya, D. A.: Geochemistry of aquifer sediments and arsenic-rich groundwaters from Kandal Province, Cambodia, Appl. Geochem., 23, 30293046, 2008.

Schulze, D. G. and Dixon, J. B.: High gradient magnetic separation of iron oxides and other magnetic minerals from soil clay, Soil Sci. Soc. Amer. J., 43, 793-799, 1979.

Shamsudduha, M., Chandler, R. E., Taylor, R. G., and Ahmed, K. M.: Recent trends in groundwater levels in a highly seasonal hydrological system: the Ganges-Brahmaputra-Meghna Delta, Hydrol. Earth Syst. Sci., 13, 2373-2385, doi:10.5194/hess-132373-2009, 2009.

Smedley, P. L. and Kinniburgh, D. G.: A review of the source, behavior, and distribution of arsenic in nature water, Appl. Geochem., 17, 517-568, 2002.

Stumm, W. and Sulzberger, B.: The cycling of iron in nature environment: considerations based on laboratory studies of heterogeneous redox processes, Geochim. Cosmochim. Acta, 56, 32333257, 1992.

Su, C. and Pulse, R. W.: Arsenate and arsenite removal by zerovalent iron: effects of phosphate, silicate, carbonate, borate, sulphate, chromate, molybdate and nitrate, relative to chloride, Environ. Sci. Technol., 35, 4562-4568, 2001.

Sutton, N. A., van der Kraan, G. M., van Loosdrecht, M. C. M., Bruining, G. M. J., and Schotting, R. J.: Characterization of geochemical constituents and bacterial populations associated with As mobilization in deep and shallow tube wells in Bangladesh, Water Res., 43, 1720-1730, 2009.

Swartz, C. H., Blute, N. K., Badruzzman, B., Ali, A., Brabander, D., Jay, J., Besancon, J., Islam, S., Hemond, H. F., and Harvey, C. F.: Mobility of arsenic in a Bangladesh aquifer: Inferences from geochemical profiles, leaching data, and mineralogical characterization, Geochim. Cosmochim. Ac., 68, 4539-4557, 2004.

Tainan Hydraulic Laboratory: The Yun-Lin offshore industrial infrastructure complexes planning, development and monitoring report, Part I, vol. 6, groundwater level and quality measurements, Taiwan, ROC, National Cheng-Kung University, 1992 2004.

Taiwan Sugar Company: Analysis and evaluation of the groundwater quality survey in Taiwan area, Water Resource Bureau, Taiwan, 2006.

Tseng, W. P.: Effects and dose-response relationships of skin cancer and blackfoot disease with arsenic, Environ. Health Persp., 19, 109-119, 1977.

van Geen, A., Rose, J., Thoral, S., Garnier, J. M., Zheng, Y., and Bottero, J. Y.: Decoupling of As and Fe release to Bangladesh groundwater under reducing conditions. Part II: Evidence from sediment incubations, Geochim. Cosmochim. Ac., 68, 34753486, 2004.

Wang, S. W., Liu, C. W., and Jang, C. S.: Factors responsible for high arsenic concentrations in two groundwater catchments in Taiwan, Appl. Geochem., 22, 460-467, 2007.

Wang, S. W., Kuo, Y. M., Kao, Y. H., Jang, C. S., Maji, S. K., Chang, F. J., and Liu, C. W.: Influence of hydrological and hydrogeochemical parameters on arsenic variation in shallow groundwater of southwestern Taiwan, J. Hydrol., 408, 286-295, 2011.

Wang, S. W., Liu, C. W., Lu, K. L., and Lin, L. H.: Biogeochemical cycling of ferric oxyhydroxide affecting As partition in groundwater aquitard, Environ. Geochem. Health, 34, 467-479, 2012. 
Wang, Y. X., Guo, H. M., Yan, S. L., Wang, R. F., and Li, Y. L.: Geochemical evolution of shallow groundwater systems and their vulnerability to contaminants: A case study at Datong Basin, Shanxi province, Chian, Science Press, Beijing, China, 102 pp., 2004 (in Chinese, with English abstract).

Waslenchuk, D. G. and Windom, H. L: Factors controlling the estuarine chemistry of arsenic, Estuar. Coastal Mar. Sci., 7, 455-464, 1978.
Water Resources Agency.: The integrated study of groundwater investigation and land subsidence prevention, Minster of Economical Affair, ROC, 2010.

WHO: Guideline for Drinking Water Quality Recommendations, WHO Org. Genera, 2002. 